\title{
Gene expression correlates with process rates quantified for sulfate- and Fe(III)-reducing bacteria in $\mathrm{U}(\mathrm{VI})$-contaminated sediments
}

\author{
Denise M. Akob ${ }^{1 \dagger \neq}$, Sang Hyon Lee ${ }^{2 \ddagger}$, Mili Sheth ${ }^{2}$, Kirsten Küsel $^{3}$, David B. Watson $^{4}$, Anthony V. Palumbo ${ }^{4}$, \\ Joel E. Kostka ${ }^{1 \dagger}$ and Kuk-Jeong Chin ${ }^{2 *}$
}

1 Florida State University, Tallahassee, FL, USA

${ }^{2}$ Department of Biology, Georgia State University, Atlanta, GA, USA

${ }^{3}$ Institute of Ecology, Friedrich Schiller University Jena, Jena, Germany

${ }^{4}$ Oak Ridge National Laboratory, Oak Ridge, TN, USA

Edited by:

Paul Bodelier, Netherlands Institute of Ecology, Netherlands

\section{Reviewed by:}

Steffen Kolb, University of Bayreuth, Germany

Dimitry Y. Sorokin, Delft University of Technology, Netherlands

\section{*Correspondence:}

Kuk-Jeong Chin, Department of

Biology, Georgia State University, 100

Piedmont Avenue, Atlanta, GA 30303,

USA.

e-mail:kchin@gsu.edu

\section{${ }^{\dagger}$ Present address:}

Denise M. Akob, Institute of Ecology,

Friedrich Schiller University Jena,

07743 Jena, Germany;

Joel E. Kostka, Schools of Biology

and Earth and Atmospheric Sciences,

Georgia Institute of Technology,

Atlanta, GA 30332, USA.

${ }^{\ddagger}$ Denise M. Akob and Sang Hyon Lee have contributed equally to this work.
Though iron- and sulfate-reducing bacteria are well known for mediating uranium(VI) reduction in contaminated subsurface environments, quantifying the in situ activity of the microbial groups responsible remains a challenge. The objective of this study was to demonstrate the use of quantitative molecular tools that target mRNA transcripts of key genes related to $\mathrm{Fe}(\mathrm{III})$ and sulfate reduction pathways in order to monitor these processes during in situ $\mathrm{U}(\mathrm{VI})$ remediation in the subsurface. Expression of the Geobacteraceae-specific citrate synthase gene $(g / t A)$ and the dissimilatory (bi)sulfite reductase gene $(d s r A)$, were correlated with the activity of iron- or sulfate-reducing microorganisms, respectively, under stimulated bioremediation conditions in microcosms of sediments sampled from the U.S. Department of Energy's Oak Ridge Integrated Field Research Challenge (OR-IFRC) site at Oak Ridge, TN, USA. In addition, Geobacteraceae-specific gltA and dsrA transcript levels were determined in parallel with the predominant electron acceptors present in moderately and highly contaminated subsurface sediments from the OR-IFRC. Phylogenetic analysis of the cDNA generated from dsrA mRNA, sulfate-reducing bacteria-specific 16S rRNA, and gltA mRNA identified activity of specific microbial groups. Active sulfate reducers were members of the Desulfovibrio, Desulfobacterium, and Desulfotomaculum genera. Members of the subsurface Geobacter clade, closely related to uranium-reducing Geobacter uraniireducens and Geobacter daltonii, were the metabolically active iron-reducers in biostimulated microcosms and in situ core samples. Direct correlation of transcripts and process rates demonstrated evidence of competition between the functional guilds in subsurface sediments. We further showed that active populations of Fe(III)-reducing bacteria and sulfate-reducing bacteria are present in OR-IFRC sediments and are good potential targets for in situ bioremediation.

Keywords: transcript level, uranium reduction, active sulfate-reducing bacteria, active metal-reducing bacteria

\section{INTRODUCTION}

Mining and milling of uranium for nuclear weapons production has resulted in widespread uranium contamination in subsurface environments across North America, South America, and Eastern Europe (Abdelouas et al., 1998). Oxidized uranium, U(VI), is highly soluble and toxic, and a potential contaminant to local drinking water supplies (Palmisano and Hazen, 2003). Immobilization of oxidized uranium can be achieved in contaminated groundwater through the reduction of $\mathrm{U}(\mathrm{VI})$ to insoluble $\mathrm{U}(\mathrm{IV})$ by indirect (abiotic) and direct (enzymatic) processes catalyzed by microorganisms (Wall and Krumholz, 2006; Kostka and Green, 2011). Current remediation practices for dealing with uranium contamination aim to promote $\mathrm{U}(\mathrm{VI})$ immobilization via natural attenuation or the biostimulation of indigenous microorganisms through a combination of $\mathrm{pH}$ neutralization and/or the addition of electron donor (Finneran et al.,
2002; Anderson et al., 2003; Wilkins et al., 2006; Groudev et al., 2010).

Dissimilatory $\mathrm{Fe}(\mathrm{III})$-reducing bacteria $(\mathrm{FeRB})$ and sulfatereducing bacteria (SRB) comprise two major groups which are capable of U(VI) reduction (Tebo and Obraztsova, 1998; Lovley et al., 2004; Sani, 2004; DiChristina, 2005b; Payne and DiChristina, 2006; Wall and Krumholz, 2006). Both FeRB and SRB can directly reduce $\mathrm{U}(\mathrm{VI})$ by using it as an electron acceptor, and a subset of these groups have been shown to conserve energy for growth via $\mathrm{U}(\mathrm{VI})$ reduction (Lovley et al., 2004). In addition, the products of microbial $\mathrm{Fe}(\mathrm{III})$ and sulfate reduction, $\mathrm{Fe}(\mathrm{II})$ and hydrogen sulfide, can react abiotically to reduce U(VI) (Liger et al., 1999; Hua et al., 2006). Therefore, FeRB and SRB are considered to have a high bioremediation potential in $\mathrm{U}(\mathrm{VI})$ contaminated subsurface sediments. Although prior research has linked the activity of these functional guilds to $\mathrm{U}(\mathrm{VI})$ immobilization in contaminated 
subsurface environments (Anderson et al., 2003; Wu et al., 2006; Akob et al., 2008; Cardenas et al., 2010), it remains difficult to directly relate the in situ activity of specific microbial groups to the environmental controls of the processes. In order to exploit the activity of FeRB and SRB for bioremediation, there remains a need to develop quantitative tools for monitoring the metabolic activity of these microbial groups in subsurface environments. Quantifying the in situ activity of $\mathrm{Fe}(\mathrm{III})$ reducers is particularly problematic and a molecular proxy for $\mathrm{Fe}(\mathrm{III})$ reduction has not yet been verified or calibrated with biogeochemical rate measurements in any sedimentary environment.

A promising strategy for quantifying the in situ metabolic activity of SRB and FeRB would be to monitor mRNA transcript levels of key genes involved in sulfate or $\mathrm{Fe}(\mathrm{III})$ reduction. The dissimilatory (bi)sulfite reductase $(\mathrm{ds} A B)$ gene is highly conserved among sulfate-reducing prokaryotes (Bacteria and Archaea) and codes for the dissimilatory (bi)sulfite reductase, which is responsible for the rate-limiting step of sulfate reduction (Wagner et al., 1998). Levels of mRNA for $d s r A B$ genes were shown to increase in pure culture studies of dissimilatory SRB as rates of sulfate reduction increased (Neretin et al., 2003; Villanueva et al., 2008) and correlated with the activity of SRB in petroleum-contaminated marine harbor sediments (Chin et al., 2008). In the case of Fe(III) reduction, no single respiration pathway has been identified as FeRB can reduce insoluble $\mathrm{Fe}(\mathrm{III})$ oxides via direct enzymatic reduction, electron shuttling pathways, or by solubilizing metals with organic ligands (DiChristina, 2005a). One approach is to target and monitor functional genes of important groups of FeRB known to be involved in $\mathrm{Fe}(\mathrm{III})$ reduction and to be abundant in contaminated subsurface sediments. Members of the Geobacteraceae family are one such group and cytochromes which are involved in $\mathrm{Fe}(\mathrm{III})$ reduction have been identified in pure cultures of different Geobacter species. However, comparative analysis of available Geobacteraceae genome sequences has revealed that these cytochromes are not conserved throughout the Geobacteraceae family (Butler et al., 2010). Furthermore, it has been known that an outer-membrane cytochrome o $m c B$ expression patterns were largely affected by environmental fluctuations, such as changes in electron acceptor availability, suggesting that monitoring $o m c B$ transcripts in Geobacter-dominated environments would not provide an accurate indication of rates of $\mathrm{Fe}(\mathrm{III})$ reduction (Chin et al., 2004). In addition to these characteristics, the Geobacteraceae family does contain a phylogenetically distinct functional gene, the citrate synthase ( glt $A$ ) gene, that codes for an enzyme involved in the incorporation of acetate into the tricarboxylic acid (TCA) cycle (Bond et al., 2005; Holmes et al., 2005). The Geobacteraceae-specific gltA gene is a good target for this group of FeRB because it is more similar to eukaryotic citrate synthase genes (Methe et al., 2003; Bond et al., 2005) distinguishing it from other prokaryotic FeRB and heterotrophs. Measurements of gltA transcripts were used as a proxy for the activity of Geobacteraceae during bioremediation of uraniumcontaminated groundwater (Holmes et al., 2005) and sediments (Akob et al., 2008). However, no study of metal or sulfate reduction in subsurface sediments has directly linked transcript level with process rates determined by geochemical methods. Therefore, in this study we quantified the transcript level of functional genes as a molecular proxy for the metabolic activity of Geobacteraceaerelated FeRB and SRB in parallel with determining process rates and the abundance of predominant electron acceptors in field samples.

\section{MATERIALS AND METHODS SITE AND SEDIMENT SAMPLE DESCRIPTION}

The study was conducted at the Oak Ridge Integrated Field Research Challenge (OR-IFRC) site of the U.S. Department of Energy's (DOE) Subsurface Biogeochemistry Research program, which is located adjacent to the Y-12 industrial complex within the Oak Ridge National Laboratory (ORNL) reservation in Oak Ridge, Tennessee. For a detailed site description refer to the ORIFRC webpage (http://www.esd.ornl.gov/orifrc/). Sediments were sampled from borehole FB107, within the Area 2 experimental plot, 5-7 m below the surface, on September 12, 2007 and from borehole FB124, Area 3 experimental plot, $1.23-15.08 \mathrm{~m}$ below the surface, on February 7, 2008 within the saturated zone, using a Geoprobe equipped with polyurethane sleeves lining the corer. Cores were aseptically sectioned under strictly anoxic conditions in an anaerobic chamber (Coy Laboratory Products, Grass Lake, MI, USA) and stored anaerobically in gastight containers at $4^{\circ} \mathrm{C}$ prior to overnight shipment to Florida State University. Sediment core sections were subsampled for total nucleic acid extraction and chemical analysis in a Coy anaerobic chamber immediately upon arrival at Florida State University.

\section{MICROCOSM DESIGN AND SAMPLING}

A microcosm experiment was performed with Area 2 FB107 sediments to assess the activity and composition of microbial communities under simulated bioremediation conditions. Microcosms were prepared as previously described (Akob et al., 2008) except that the sediment was diluted 1:5 (w/v) with sterile, anaerobic artificial groundwater (composition per liter: $1.0 \mathrm{~g} \mathrm{NaCl}, 0.4 \mathrm{~g}$ $\mathrm{MgCl}_{2} \cdot 6 \mathrm{H}_{2} \mathrm{O}, 0.1 \mathrm{~g} \mathrm{CaCl}_{2} \cdot 2 \mathrm{H}_{2} \mathrm{O}, 0.5 \mathrm{~g} \mathrm{KCl}, 1 \mathrm{ml}$ selenite-tungstate solution, $1 \mathrm{ml}$ trace elements solution, and $5.0 \mathrm{mM} \mathrm{NaHCO} 3$; modified from Widdel and Bak, 1992). Three replicate microcosms were established for each of the following treatments: amendment with ethanol, amendment with ethanol + molybdate, amendment with acetate, and amendment with acetate + molybdate; with molybdate added to inhibit sulfate reduction. Sulfate $(2.5 \mathrm{mM}$ final concentration), molybdate ( $5 \mathrm{mM}$ final concentration), and electron donors (5 $\mathrm{mM}$ ethanol or acetate) were added from sterile anaerobic stocks.

Microcosms were sampled by removing $\sim 5 \mathrm{ml}$ every $1-3$ days using a sterile syringe equipped with an $18 \mathrm{G}$ needle under a $\mathrm{H}_{2} / \mathrm{N}_{2}$ atmosphere in a Coy anaerobic chamber. $\mathrm{HCl}$ extractable $\mathrm{Fe}(\mathrm{II})$ content was measured as previously described (Akob et al., 2008). Porewaters were extracted for determination of uranium and sulfate concentrations and carbon substrate utilization as previously described (Akob et al., 2008). At select time points, samples from each replicate microcosm were collected and pooled for cultivation-independent microbial community characterization by centrifuging samples at $7,000 \times g$ for $7 \mathrm{~min}$, discarding the supernatant, and freezing the solid phase at $-80^{\circ} \mathrm{C}$ immediately until nucleic acid extraction. 


\section{CHEMICAL CHARACTERIZATION OF SEDIMENTS}

Soluble chemistry was determined on sediment samples from each depth interval by extracting sediment in a $1: 1(\mathrm{w} / \mathrm{v})$ ratio in deionized water followed by a $1 \mathrm{~h}$ incubation shaking at $200 \mathrm{rpm}$. Samples were centrifuged at $5,000 \times g$ for $5 \mathrm{~min}$, followed by filtration through a $0.22-\mu \mathrm{m}$ nylon syringe filter. The liquid phase was then analyzed for $\mathrm{SO}_{4}^{2-}$ by the $\mathrm{BaSO}_{4}$ turbidimetric method (Rodier, 1975), for nitrate using the colorimetric method described by Cataldo et al. (1975), and the $\mathrm{pH}$ was measured with a calibrated digital pH meter (McLean, 1982). Samples for uranium determination were acidified with nitric acid and stored at $-20^{\circ} \mathrm{C}$ prior to kinetic phosphorescence analysis using a KPA-11 analyzer (Chem-Chek Instruments, Richland, WA, USA; Brina and Miller, 1992).

Total iron and $\mathrm{Fe}(\mathrm{II})$ in each depth interval were determined by oxalate extraction and colorimetric quantification using ferrozine, as previously described (Kostka and Luther, 1994). In brief, sediment samples for $\mathrm{Fe}$ (II) determination were kept under strictly anaerobic conditions and were extracted in anaerobic oxalate (0.2 M ammonium oxalate, $0.2 \mathrm{M}$ oxalic acid, $\mathrm{pH} 2.5)$ for $4 \mathrm{~h}$ in the dark, shaking at $200 \mathrm{rpm}$. After extraction, samples were centrifuged for $5 \mathrm{~min}$ at 5,000 rpm and the extract was added to ferrozine reagent (50 $\mathrm{mM}$ HEPES, $0.1 \%$ ferrozine, $\mathrm{pH}$ 7.0). The extract and ferrozine were incubated for $10 \mathrm{~min}$ in the dark then measured spectrophotometrically at $562 \mathrm{~nm}$. Sediment samples for total Fe determinations were dried aerobically then extracted in oxalate in the dark at room temperature by shaking at $200 \mathrm{rpm}$ for $4 \mathrm{~h}$. After extraction, samples were centrifuged for $5 \mathrm{~min}$ at $5,000 \mathrm{rpm}$ and the extract was reacted with total Fe reagent (1\% hydroxylamine hydrochloride in ferrozine) for $4 \mathrm{~h}$ in the dark prior to measurement on a spectrophotometer at $562 \mathrm{~nm}$ (Green et al., 2010).

\section{EXTRACTION OF TOTAL RNA, MRNA, AND DNA}

Total RNA was extracted from a total of $3 \mathrm{ml}$ of microcosm sediments and $3 \mathrm{~g}$ of in situ borehole sediments, and the recovered RNA was treated with RNase-free DNase to remove any contaminating DNA according to previously described methods (Chin et al., 2008). In order to prevent coextraction of inhibitory compounds such as humic acids and clay minerals polyvinylpyrrolidone K25 (PVP) was used during the total RNA extraction. Then, the extracted RNA was purified with a Sephadex (G-100) column filtration. To further purify the RNA, it was precipitated with sodium acetate, glycogen, and ethanol at $-80^{\circ} \mathrm{C}$ for $30 \mathrm{~min}$, purified RNA was recovered by centrifugation. The mRNA was enriched and isolated by a magnetic bead hybridization method with MICROB Express purification system (Applied Biosystems, Foster City, CA, USA), and large ribosomal RNA (16S and 23S rRNA) were removed by this protocol procedure. mRNA isolation using magnetic bead hybridization procedure followed additional purification provided high purity of mRNA. To remove any residue of small RNAs (including tRNA and 5S rRNA), the enriched mRNA was further purified with the glass fiber-based filtration method with the MEGAclear purification system (Applied Biosystems). DNA contamination was checked with agarose gel electrophoresis following reverse transcription-polymerase chain reaction (RT-PCR) by performing control experiments in which no reverse transcriptase was added to the extracted RNA before the PCR step. Concentration of RNA and mRNA was determined and the purity was checked with a Biophotometer (Eppendorf, Hamburg, Germany) and a NanoDrop 2000 Spectrophotometer (Thermo Scientific, Wilmington, DE, USA). Purified RNA and mRNA were stored at $-80^{\circ} \mathrm{C}$. Total DNA was extracted from a total of $2 \mathrm{ml}$ of microcosm sediments according to previously described methods (Chin et al., 2008).

\section{PCR PRIMERS}

The primers used in this study are listed in Table 1. The primer pairs CS375nF/CS598nR and DSR1F/DSRQP3R were used for real-time PCR quantification of Geobacteraceae-specific gltA, and bacterial and archaeal $d s r A$ mRNA transcripts, respectively. The primer pairs CS18nF/CS821nR and CS1Fdeg/CS2Rdeg were used for reverse transcription PCR of Geobacteraceae-specific gltA transcript and for phylogenetic analysis. The primer pair DSR2MF/DSR4R was used for PCR amplification of bacterial and archaeal $d s r A B$ DNA and for phylogenetic analysis. The primer pair DSV230f/DSV838r was used for reverse transcription PCR of sulfate-reducing bacteria-specific 16S rRNA and for phylogenetic analysis. Primers were evaluated for quantitative real-time PCR as described earlier (Chin et al., 2004). The resulting conditions were experimentally checked using genomic DNA isolated from Desulfovibrio desulfuricans subsp. desulfuricans and Geobacter metallireducens cultures for $d s r$ gene and gltA gene, respectively. All primers were synthesized by Integrated DNA Technologies (IDT; San Jose, CA, USA). To determine whether the primers were suitable, gene-specific qualitative PCR was performed before quantitative PCR. PCR products were amplified from cDNA generated by reverse transcription with the appropriate primers using the following conditions: $95^{\circ} \mathrm{C}(5 \mathrm{~min}) ; 40$ cycles of $95^{\circ} \mathrm{C}(40 \mathrm{~s})$; $52^{\circ} \mathrm{C}(1 \mathrm{~min}) ; 72^{\circ} \mathrm{C}(1 \mathrm{~min})$ followed by a final extension at $72^{\circ} \mathrm{C}$ for $10 \mathrm{~min}$. Cloning and sequencing verified the specificity of PCR products. Only the primer combinations, which amplified well, were further used for real-time PCR quantification. In order to overcome the effects of any remaining inhibitors that are not eliminated during RNA and mRNA extraction, Bovine serum albumin (BSA) was added for all PCR assays to provide some resistance to inhibitors during the PCR step. The choice of DNA polymerases which can have a large impact on resistance to inhibition was extensively tested, and DNA polymerases which are among the available choices the most sensitive to inhibition were selected for further analysis.

\section{REVERSE TRANSCRIPTION PCR AND REAL-TIME PCR QUANTIFICATION OF MRNA TRANSCRIPTS}

cDNA synthesis was performed with $d s r A$-specific, gltA-specific, and SRB-specific 16S rRNA reverse primers, $0.5 \mu \mathrm{g}$ template mRNA or total RNA, and MultiScribe ${ }^{\mathrm{TM}} \mathrm{MuLV}$ reverse transcriptase (200 U; Applied Biosystems, Foster City, CA, USA) incubated at $25^{\circ} \mathrm{C}$ for $20 \mathrm{~min}$ followed by at $37^{\circ} \mathrm{C}$ for $120 \mathrm{~min}$, and enzyme inactivation at $80^{\circ} \mathrm{C}$ for $5 \mathrm{~s}$.

The cDNAs were amplified with gene-specific primers and the resulting amplicons were purified. The purified $d s r A$ or gltA RTPCR amplicons were quantified and prepared for serial dilution, which were used as calibration standards for the real-time PCR 
Table 1 | Primers used in this study.

\begin{tabular}{|c|c|c|c|}
\hline Target & Primer & Sequence $\left(5^{\prime}-3^{\prime}\right)$ & Reference \\
\hline \multirow[t]{6}{*}{ Geobacteraceae-specific citrate synthase $(g / t A)$} & CS375nF & AACAAGATGRCMGCCTGGG & Akob et al. (2008) \\
\hline & CS598nR & TCRTGGTCGGARTGGAGAAT & \\
\hline & CS18nF & CTCGCGRCATYCGCAGTCT & This study, modified from Holmes et al. (2005) \\
\hline & CS821nR & TGRCCGGCRTTCAGGGTAT & \\
\hline & CS1Fdeg & CCGYGACATYCGCWGYCT & \\
\hline & CS2Rdeg & TGRCCGGMRTTCAGGGTAT & \\
\hline \multirow[t]{4}{*}{ Dissimilatory sulfite reductase (dsrA) } & DSR1F & ACSCACTGGAAGCACG & Wagner et al. (1998) \\
\hline & DSR4R & GTGTAGCAGTTACCGCA & \\
\hline & DSROP3R & CGCATGGTRTGRAARTG & This study \\
\hline & DSR2MF & CTGGAARGAYGACATCAA & This study, modified from Wagner et al. (1998) \\
\hline \multirow[t]{2}{*}{ Sulfate-reducing bacteria-specific $16 \mathrm{~S}$ rRNA } & DSV230f & GRGYCYGCGTYYCATTAGC & Daly et al. (2000) \\
\hline & DSV838r & SYCCGRCAYCTAGYRTYCATC & \\
\hline
\end{tabular}

quantification (qPCR), and stored at $-20^{\circ} \mathrm{C}$. The detection limits of PCR assays were determined from three independent measurements as previously described (Chin et al., 2004). All assays had a minimum sensitivity of $10^{0}-10^{1}$ target molecules per reaction. The precision and reproducibility of quantification were carefully optimized, and correct lengths of PCR products were verified (Chin et al., 2004). The cDNA which was generated with $d s r A$-specific or gltA-specific primers was quantified with real-time quantitative PCR, using SYBR Green. All reactions were carried out in $20 \mu \mathrm{l}$ reaction volume containing 0.02 units of iProof High Fidelity polymerase (BioRad, Hercules, CA, USA), buffer, 2.5 pmol each dNTP, bovine serum albumin, and 20 pmol of each primer pair. The temperature profile was composed of an initial activation step at $50^{\circ} \mathrm{C}$ for $2 \mathrm{~min}$ and denaturation at $98^{\circ} \mathrm{C}$ for $30 \mathrm{~s}$, followed by 40 cycles of denaturation at $98^{\circ} \mathrm{C}$ for $10 \mathrm{~s}$, annealing at $52(\mathrm{glt} A)$ or $53^{\circ} \mathrm{C}(\mathrm{dsr} A)$ for $2 \mathrm{~s}$, and elongation at $65^{\circ} \mathrm{C}$ for $32 \mathrm{~s}$, with a final extension step at $65^{\circ} \mathrm{C}$ for $6 \mathrm{~min}$. In order to prevent primer dimer formation during $\mathrm{qPCR}$, optimal primer pairs were designed and appropriate primer concentrations were used. The primer optimization matrix was performed with different amounts of cDNA to exclude concentration-depending phenomena, and qPCR assays were performed with controls without template (NTCs) followed by a dissociation curve to check for primer dimers and non-specific products. If more than a single peak was observed on the dissociation curve, the concentration of primer and $\mathrm{MgCl}_{2}$ was optimized. An amount of primer and $\mathrm{MgCl}_{2}$ that forms no primer dimers and gives optimal amplification was used for qPCR assays of all the samples. qPCR analysis of the CDNA was carried out with the Applied Biosystems 7500 Real-Time PCR system using 7500 Real-Time PCR System Sequence Detection Software (Version 1.3.1).

\section{CLONING, SEQUENCING, AND PHYLOGENETIC ANALYSIS}

Six libraries were generated with the $d s r A$ - or gltA-specific RT-PCR amplicons of short fragment (116 and 224 bp lengths amplified with primers DSR1F/DSRQP3R and CS375nF/CS598nR, respectively) obtained from mRNA, which were isolated from microcosm, Area 2, and Area 3 borehole sediments, respectively, to confirm the specificity of the real-time PCR products. Three libraries were generated with gltA-specific RT-PCR amplicons of long fragments (ca. 807-891 bp lengths, amplified with primers CS18nF/CS821nR or CS1Fdeg/CS2Rdeg) for phylogenetic analysis. Additionally, one library was generated with $d s r A B$ gene amplicons of long fragments obtained from DNA isolated from microcosm sediment (ca. $1.4 \mathrm{~kb}$ length, amplified with primers DSR2MF/DSR4R), and another library was generated with SRBspecific 16S rRNA RT-PCR amplicons (ca. 610 bp length, amplified with primers DSV230f/DSV838r) obtained from total RNA isolated from Area 2 borehole sediment for phylogenetic analyses. Amplicons were cloned in to the pCR2.1-TOPO vector with the One Shot TOPO TA cloning kit or pCR4Blunt-TOPO vector with the Zero Blunt TOPO PCR Cloning Kit (Invitrogen). A total of 30 clones were randomly selected from each gltA mRNA library, SRB-specific $16 \mathrm{~S}$ rRNA library, and $d s r A B$ gene library, and plasmid inserts were sequenced with M13 primers using an ABI 3730xl DNA Analyzer. Sequences were compared to the GenBank database using the BLAST program (Altschul et al., 1990). Phylogenetic analysis was performed using the ARB software package (Ludwig et al., 2004). The ARB_EDIT tool was used for automatic sequence alignment, and the sequences were checked and corrected manually. Trees were calculated from aligned nucleotide and deduced gltA amino acid sequences with the ARB software package, using neighbor-joining, FITCH, and maximum likelihood methods. Trees constructed with amino acid and nucleotide sequences yielded similar results. Tree topology was constructed from nucleotide sequences using neighborjoining analysis with Jukes-Cantor distance correction method and verified by maximum likelihood algorithm.

\section{NUCLEOTIDE SEOUENCE ACCESSION NUMBERS}

The nucleotide sequences of $d s r$, gltA, and 16S rRNA genes retrieved in this study were deposited in the EMBL database under the accession numbers HE856492-HE856617.

\section{RESULTS \\ EXPRESSION OF dsrA AND gltA DURING BIOSTIMULATION}

The addition of ethanol or acetate stimulated sulfate reduction only in treatments without molybdate, whereas $\mathrm{Fe}$ (III) reduction [accumulation of $\mathrm{Fe}(\mathrm{II})$ ] was observed in all treatments (Figures 1 and 2). DsrA transcript levels correlated with sulfate 


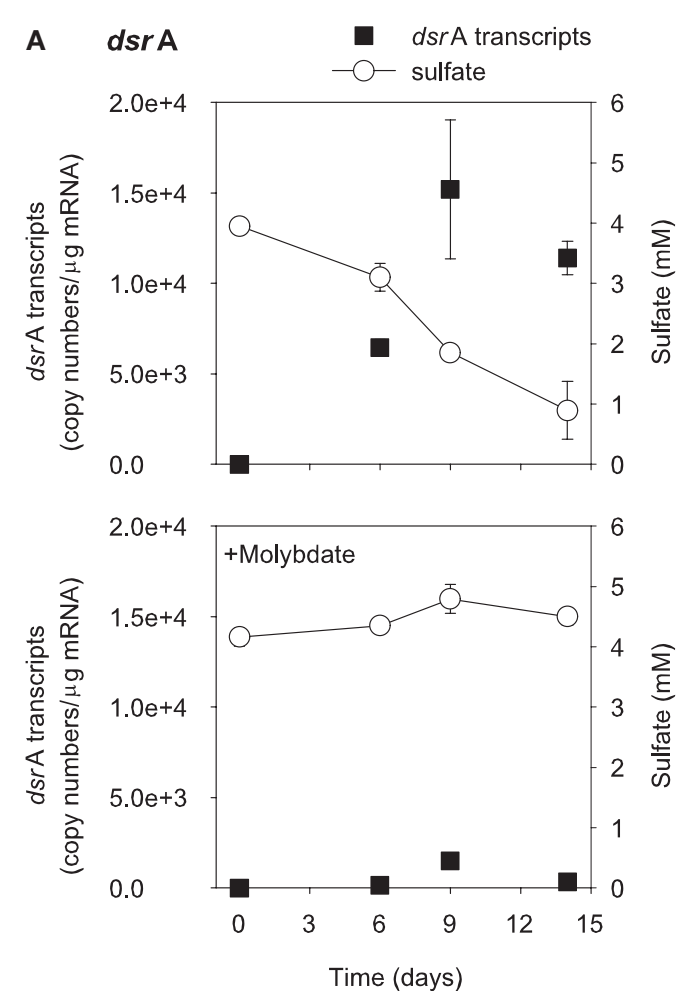

FIGURE 1 | Expression of $d s r A$ (A) and gltA (B) genes related to electron acceptor reduction in ethanol-biostimulated microcosms.

The lower panels show treatments amended with molybdate as an

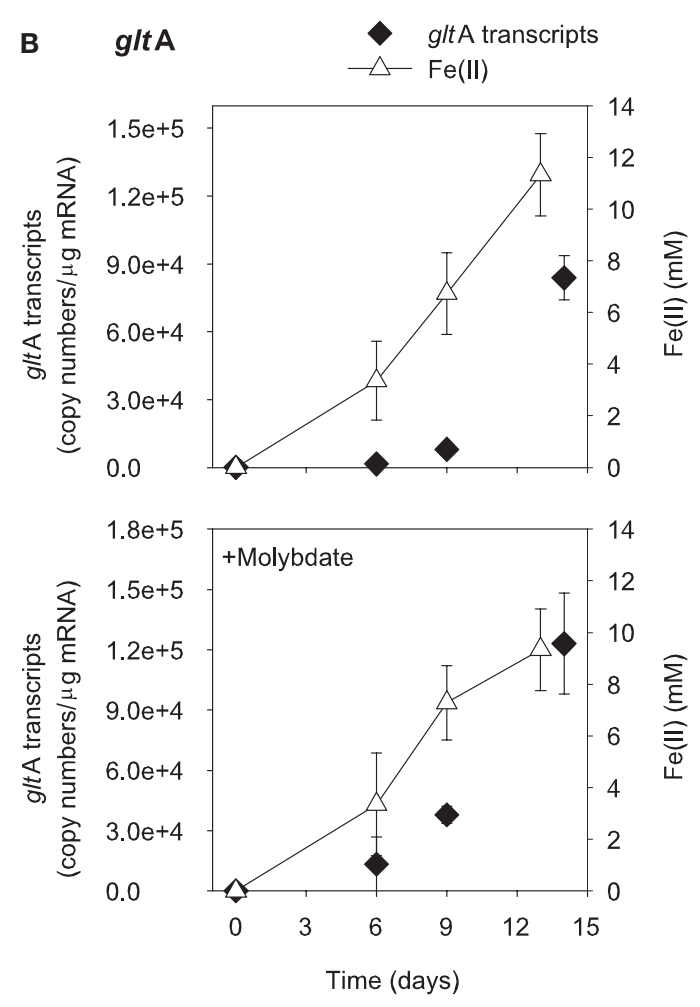

inhibitor of sulfate reduction. Data are means \pm standard deviations of triplicate determinations on a pooled sample from triplicate microcosms. reduction activity in the treatments amended with carbon substrates (Figures $\mathbf{1 A}$ and $\mathbf{2 A}$ ). In the ethanol-amended treatment, $d s r A$ transcripts increased linearly to a maximum of $1.52 \times 10^{4}$ copies per $\mu \mathrm{g}$ mRNA as $\sim 3.2 \mathrm{mM}$ sulfate was reduced at day 9 and transcript levels decreased as sulfate concentrations were depleted to below $2 \mathrm{mM}$ (Figure 1A). In the acetate-amended treatment, $d s r A$ transcript levels were lower with $7.29 \times 10^{3}$ copies per $\mu \mathrm{g}$ mRNA detected in parallel with the depletion of $1.3 \mathrm{mM}$ sulfate at day 22 when sulfate reduction ceased (Figure 2A). In treatments where molybdate inhibited sulfate reduction (Figures $1 \mathrm{~A}$ and $\mathbf{2 A}$ ), $d s r A$ transcripts were detected at a relatively low level $\left(<2.00 \times 10^{3}\right.$ copies per $\mu \mathrm{g}$ mRNA), and little to no change was observed with time.

Levels of Geobacteraceae-specific gltA transcripts correlated with $\mathrm{Fe}$ (III) reduction in both ethanol- and acetate-amended treatments (Figures $\mathbf{1 B}$ and $\mathbf{2 B}$ ). The majority of $\mathrm{Fe}(\mathrm{II})$ accumulated between days 5 and 8 and the addition of molybdate did not impact the amount of $\mathrm{Fe}$ (II) produced or the level of transcripts (Figures 1B and 2B). In the ethanol only treatment at day $22,8.4 \times 10^{4} \mathrm{gltA}$ transcript copies per $\mu \mathrm{g}$ mRNA were observed, whereas $1.2 \times 10^{5} \mathrm{gltA}$ copies per $\mu \mathrm{g}$ mRNA were observed on the same day in the ethanol with molybdate treatment (Figure 1B). Approximately 9.8 and $9.6 \mathrm{mM} \mathrm{Fe}(\mathrm{II})$ accumulated and the highest numbers of $g l t A$ transcripts were $8.4 \times 10^{4}$ and $1.2 \times 10^{5}$ (copies per $\mu \mathrm{g} \mathrm{mRNA}$ ) in the acetate and acetate with molybdate treatments, respectively (Figure 2B).
During the initial 5 days of incubation, $\mathrm{U}(\mathrm{VI})$ concentrations decreased in all treatments, however, a more substantial decrease was observed in ethanol treatments (data not shown). U(VI) concentrations increased in conjunction with $\mathrm{Fe}(\mathrm{III})$ reduction and subsequently decreased by day 16 in the all treatments. Approximately 12 and $5 \mu \mathrm{M} \mathrm{U}(\mathrm{VI})$ was removed from solution in the ethanol and acetate treatments, respectively. Ethanol was consumed from days 0 to 6 in ethanol-amended treatments and was incompletely oxidized to acetate (Figures $\mathbf{3 A}$ and $\mathbf{3 B}$ ). Acetate accumulated until day 6 and then was slowly consumed for the remainder of the incubation. In acetate-amended treatments, acetate was consumed starting on day 4 and ceased on day 22 of the incubation (Figures 3C and 3D).

\section{IN SITU METABOLIC ACTIVITY OF SRB AND FeRB IN CONTAMINATED SEDIMENTS}

Expression of $d s r A$ and $g l t A$ were quantified in parallel with the determination of the most abundant electron acceptors present in core samples from uranium-contaminated subsurface sediments (nitrate, sulfate, iron, uranium). Significant transcripts were detected in all sediments sampled from the OR-IFRC. Overall, transcript levels were variable and approached the limit of detection from subsurface regions exposed to moderate (FB107, Figure 4) and high levels (FB124, Figure 5) of uranium contamination. In borehole FB124, from the highly contaminated Area 3 of the ORFRC, expression of $d s r \mathrm{~A}$ and $g l t \mathrm{~A}$ transcripts 


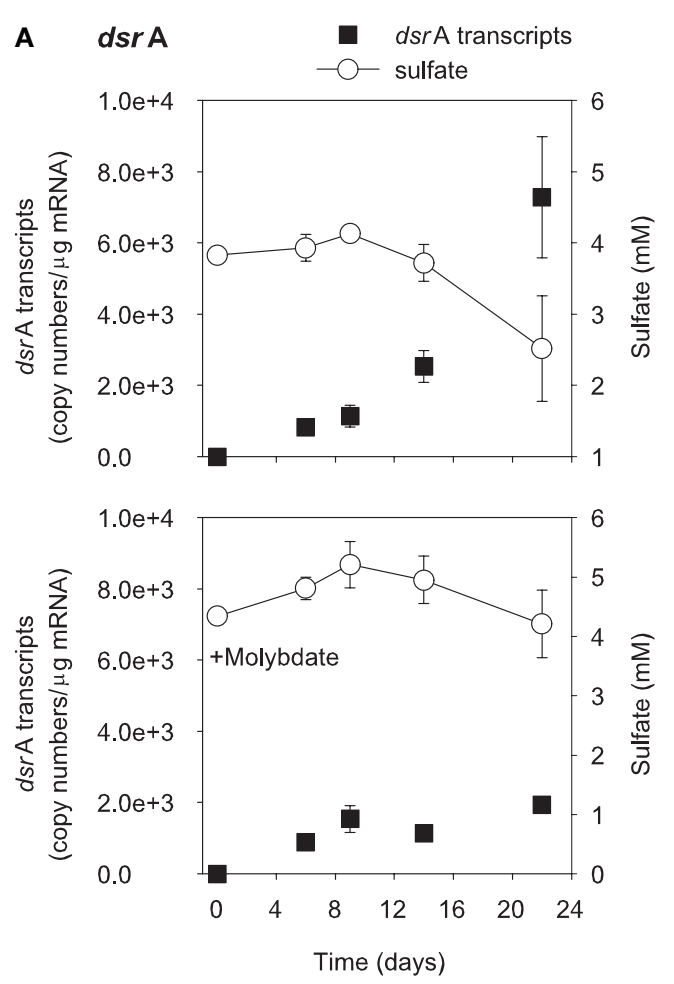

FIGURE 2 | Expression of dsrA (A) and gltA (B) genes related to electron acceptor reduction in acetate-biostimulated microcosms. The lower panels show treatments amended with molybdate as an

and the geochemistry indicated ongoing microbial activity in a depth of 9.75-9.88 m below surface (Figure 5). The highest level of $d s r \mathrm{~A}$ and glt A transcripts were observed in this depth interval along with low sulfate and high $\mathrm{Fe}(\mathrm{II})$ concentrations. The other depth intervals of FB124 had a low level of gene expression and little geochemical evidence of sulfate or iron reduction. In contrast, depth profiling of gene expression and geochemistry in FB107 did not provide clear evidence for in situ microbial activity (Figure 4). In this core, the level of transcripts was much lower than in FB124 (Figures 4C and 5C, note different scales) and the depth interval (6.30-6.34 $\mathrm{m}$ below surface) with the highest level of transcripts did not have high $\mathrm{Fe}$ (II) or low sulfate concentration (Figure 4). The region with the highest Fe(II) concentration (5.84$5.89 \mathrm{~m}$ below surface) had moderate expression of gltA. Although nitrate concentrations were not elevated in sediments from FB107 (Figure 4), groundwater sampled from nearby wells has routinely shown nitrate concentrations in the $2 \mathrm{mM}$ range (Akob et al., 2008; Green et al., 2010, 2012). Thus, though active Fe(III) and sulfate reducers were detected, their metabolism was likely inhibited by the presence of substantial concentrations of the competing electron acceptor, nitrate.

\section{PHYLOGENY OF ACTIVE SRB AND FERB DURING BIOSTIMULATION AND} IN IN SITU CONTAMINATED SEDIMENTS

The phylogeny of active sulfate and iron-reducers during biostimulation and in in situ contaminated sediments was evaluated. Phylogenetic analyses of Geobacteraceae-specific gltA mRNA

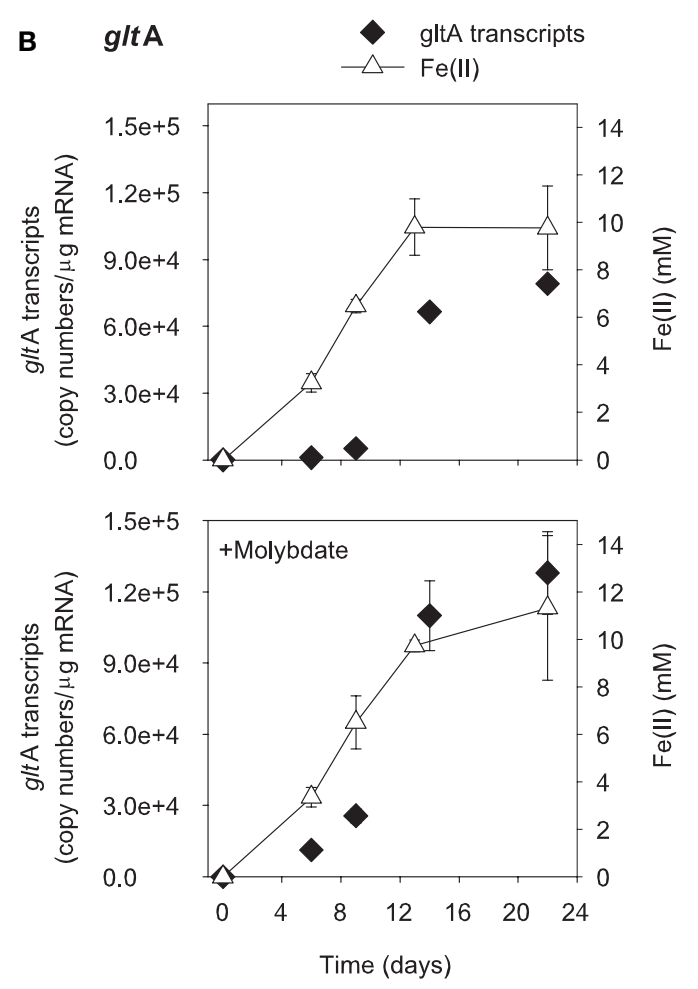

inhibitor of sulfate reduction. Data are means \pm standard deviations of triplicate determinations on a pooled sample from triplicate microcosms.

sequences ( $\sim 891 \mathrm{bp}$ length) retrieved from Area 2 ethanolamended microcosms demonstrated that groups closely related to G. uraniireducens and G. daltonii FRC-32 are metabolically active and abundant (Figure 6A). BLAST analysis of short gltA mRNA sequences (224 bp length) confirmed the specificity of qPCR amplicons, and also suggested that groups closely related to Geobacter species are active and abundant in Area 2 sediments (Table 3). No amplicons were obtained from mRNA or DNA extracted from OR-IFRC sediments with the primer pair DSR1F/DSR4R, which previously recovered $d s r A B$ DNA sequences from many other environments and amplified the $d s r A B$ genes from a pure culture of Desulfovibrio desulfuricans in this study. However, the primer pair DSR2MF/DSR4R, which amplifies a smaller $(1.4 \mathrm{kbp})$ fragment of $d s r A B$ in both Bacteria and Archaea, amplified portions of the $d s r \mathrm{AB}$ sequences from DNA but not from mRNA extracted from ethanol-amended microcosms. BLAST analysis of $d s r A B$ DNA sequences ( $~ 850$ bp length) demonstrated the presence of groups belonging to Desulfovibrionaceae (clones OR-IFRC-DSRMd-16 and OR-IFRC-DSRMd-48) and Desulfobacteraceae (clones OR-IFRC-DSRMd-19 and OR-IFRCDSRMd-39) in Area 2 microcosm sediments. Clone OR-IFRCDSRMd-16 had 79\% sequence similarity to $d s r A B$ genes of Desulfovibrio aminophilus strain DSM 12254 (AY626029), whereas, clone OR-IFRC-DSRMd-48 was $99 \%$ related to $d s r A B$ genes of $D$. desulfuricans (AJ249777). The Desulfobacteraceae clones OR-IFRC-DSRMd-19 and OR-IFRC-DSRMd-39 were related to dsrAB genes of Desulfobacterium cetonicum (77\%, AF420282) and 

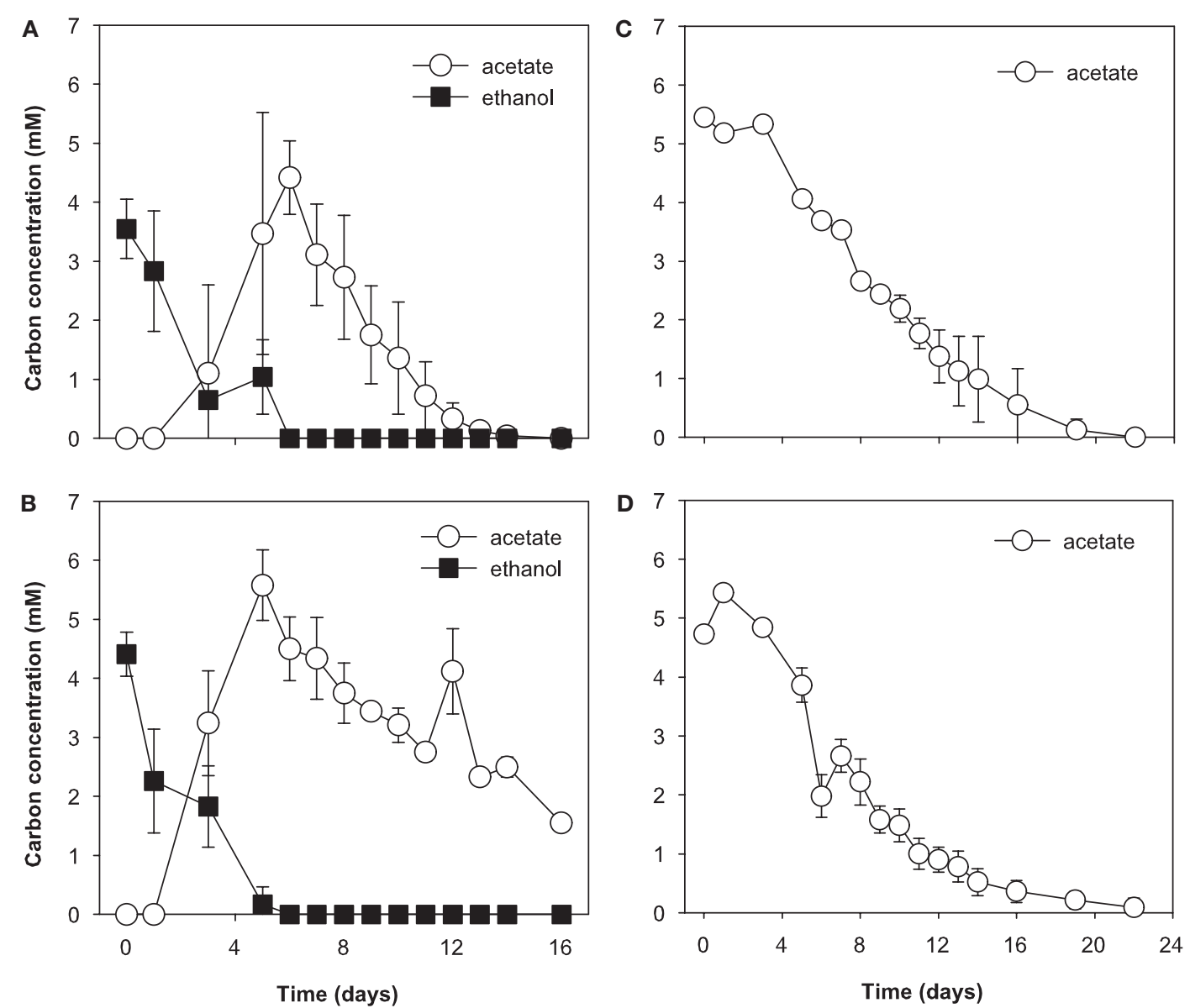

FIGURE 3 | Electron donor utilization biostimulated microcosms. (A) Ethanol only treatment, (B) ethanol with molybdate, (C) acetate-only, and (D) acetate with molybdate; molybdate was added as a sulfate reduction inhibitor. Data are means \pm standard deviations of triplicate microcosms.

uncultured prokaryote clone DB_dsr12 (84\%, EU350969), respectively. BLAST analysis of short $d s r$ A mRNA sequences (116 bp length) retrieved from ethanol-amended microcosms confirmed the specificity of qPCR amplicons, and also suggested that groups closely related to Desulfovibrio species are metabolically active and abundant in biostimulated Area 2 sediments (Table 2).

Phylogenetic analyses of gltA mRNA sequences ( $~ 891 \mathrm{bp}$ length) retrieved from in situ Area 2 borehole sediments demonstrated that groups closely related to G. uraniireducens, G. daltonii FRC-32, and G. metallireducens are metabolically active and abundant in situ (Figure 6A). This result corresponds with the result obtained in the Area 2 microcosm study, and also indicates a higher diversity than in ethanol-amended microcosms. BLAST analysis of short gltA mRNA sequences (224 bp length) confirmed the specificity of qPCR amplicons, and also suggested that groups closely related to Geobacter species are active and abundant in the Area 2 sediments (Table 3). BLAST analysis of short $d s r A$ mRNA sequences ( $116 \mathrm{bp}$ length) retrieved from Area 2 in situ sediments confirmed the specificity of qPCR amplicons, and also suggested that groups closely related to Desulfovibrio species are active and abundant in situ (Table 2). In addition, phylogenetic analysis of SRB-specific 16S rRNA sequences ( 610 bp length) confirmed the abundance and activity of groups belonging to Geobacteraceae, Desulfovibrionaceae, and Desulfobacteraceae in Area 2 in situ sediments (Figure 6B).

Phylogenetic analyses of gltA mRNA sequences ( $~ 891 \mathrm{bp}$ length) retrieved from in situ Area 3 borehole sediments demonstrated that only a group closely related to $G$. daltonii is active and dominant (Figure 6A). BLAST analysis of short gltA mRNA sequences confirmed the specificity of qPCR amplicons, and also suggested that a group closely related to $G$. daltonii is active and abundant in Area 3 sediments (Table 3). BLAST analysis of short dsrA mRNA sequences (116 bp length) retrieved from Area 3 in situ borehole sediments confirmed the specificity of qPCR amplicons, and also suggested that groups closely related to Desulfovibrio and Desulfotomaculum species are active and abundant in these subsurface sediments (Table 2).

\section{DISCUSSION}

\section{METABOLIC ACTIVITY OF FeRB AND SRB IN} URANIUM-CONTAMINATED SUBSURFACE SEDIMENTS

Bioremediation, via biostimulation of microbial communities by addition of large quantities of electron donor, is a proposed strategy for uranium immobilization at many uranium-contaminated 


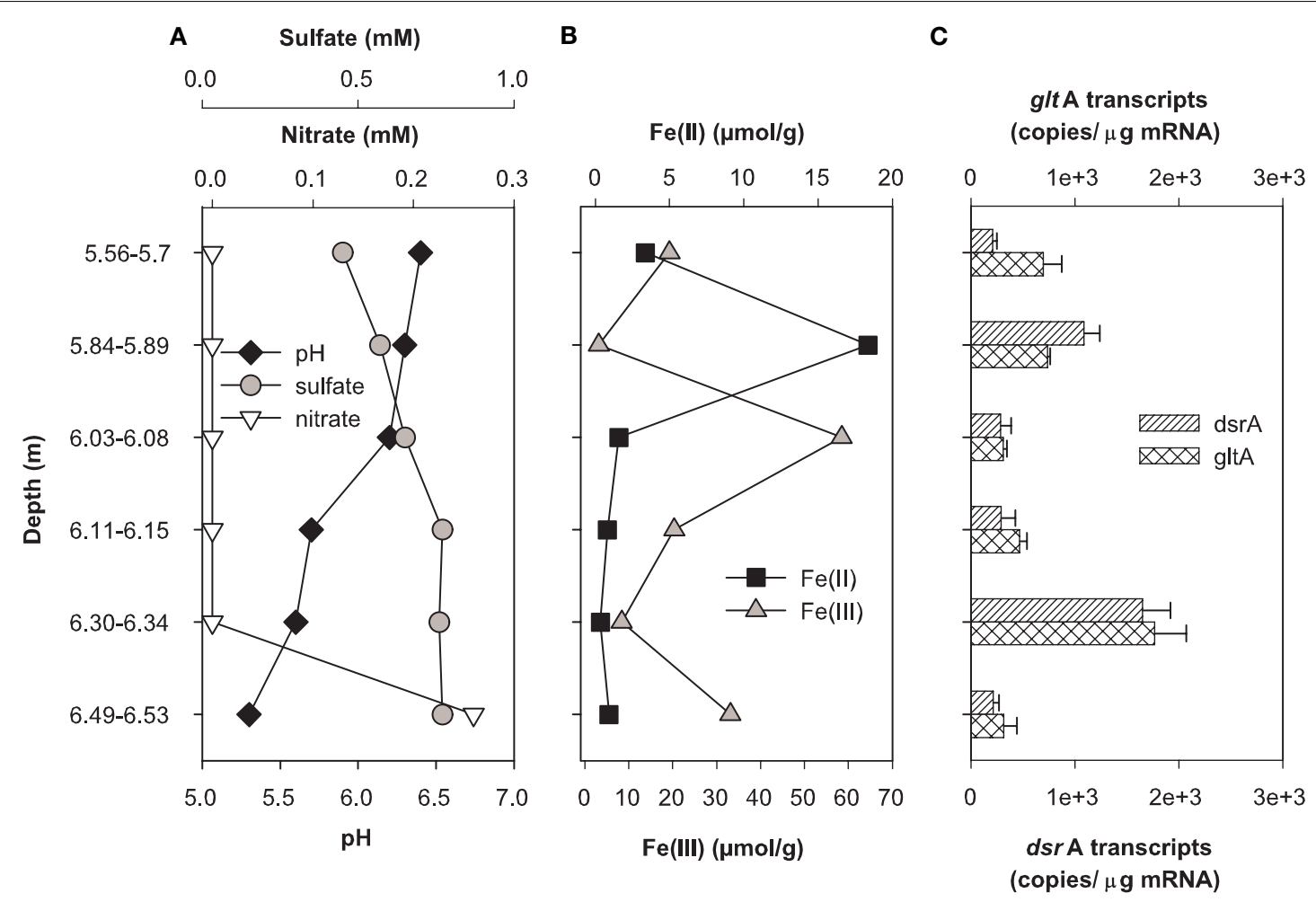

FIGURE 4 | Geochemistry (A,B) and levels of dsrA and gltA transcripts (C) in the depth interval from 1.23 to $15.08 \mathrm{~m}$ of Area 2 borehole FB107. Values for transcript levels are means \pm standard deviations of triplicate determinations on a pooled sample from triplicate borehole sediment samples. Nitrate, sulfate, $\mathrm{pH}$, and iron data were reported previously as supplemental material in Green et al. (2010). Uranium was not analyzed. sites managed by the U.S. DOE. The addition of electron donors, e.g., ethanol and acetate, has been shown previously to stimulate the reductive removal of $\mathrm{U}(\mathrm{VI})$ in the subsurface of many of these sites (e.g., Anderson et al., 2003; Wu et al., 2006; Akob et al., 2008; Michalsen et al., 2009). Iron(III)-reducing bacteria (FeRB) and SRB have been identified as the functional guilds of microorganisms likely to catalyze $\mathrm{U}(\mathrm{VI})$ reduction during in situ bioremediation experiments conducted at the DOE's OR-IFRC site or the Old Rifle site in Colorado, in particular (Kostka and Green, 2011). Although a large number of studies have shown that the abundance of these microbial groups increases in response to electron donor addition and under metal-reducing conditions, the activity of specific metal-reducing bacterial populations (e.g., SRB and FeRB) remains difficult to assess under in situ conditions.

Biogeochemical methods for quantifying rates of sulfate or $\mathrm{Fe}$ (III) reduction (Canfield et al., 2005) are tedious and time consuming and thus cannot be easily applied over the scales necessary for monitoring in situ bioremediation. Thus, a quantitative molecular approach for the determination of $\mathrm{Fe}$ (III) or sulfate reduction activity would aid in diagnosing the success of bioremediation strategies along with in situ controls of the enzymatically catalyzed processes. A method that focuses on the gene expression of metal-reducing bacterial populations would be ideal since the active populations could be identified along with the quantification of activity. The desired target should be a phylogenetically informative gene that is highly conserved and unique to a distinct group and for which expression patterns are correlated to metabolic rates. The dissimilatory (bi)sulfite reductase $(d s r A B)$ gene provides such a target for SRB since it is highly conserved and codes for the enzyme responsible for the rate-limiting step of sulfate reduction. In the case of FeRB, such a robust gene target has not been identified because numerous pathways exist for metal respiration that involved a number of different proteins, which are poorly conserved (DiChristina, 2005a).

The expression of respiratory genes involved in $\mathrm{Fe}$ (III) reduction was shown to correlate with rates of metabolism in pure cultures of the Geobacteraceae (Chin et al., 2004). However, transcript level of respiratory genes was shown to respond to other parameters besides rates of metabolism and growth (Chin et al., 2004). It was proposed that the expression of genes linked to central carbon metabolism may provide an alternative proxy for metabolic rates of Fe(III)-reducing members of the Geobacteraceae (Holmes et al., 2005). Geobacter species are known to predominate under Fe(III)-reducing conditions (Bond et al., 2005; Holmes et al., 2005) and are in fact capable of outcompeting other FeRB in Fe(III)-rich environments (Rooney-Verga et al., 1999; Snoeyenbos-West et al., 2000; Röling et al., 2001). In addition, Geobacteraceae often predominate in uranium-contaminated subsurface sediments undergoing bioremediation, including the above mentioned DOE sites at Oak Ridge, TN, USA and in Rifle, CO, USA (Holmes et al., 2002, 2007; Anderson et al., 2003; North et al., 2004). Thus in this study, we targeted the citrate synthase $(g l t A)$ gene that is unique 


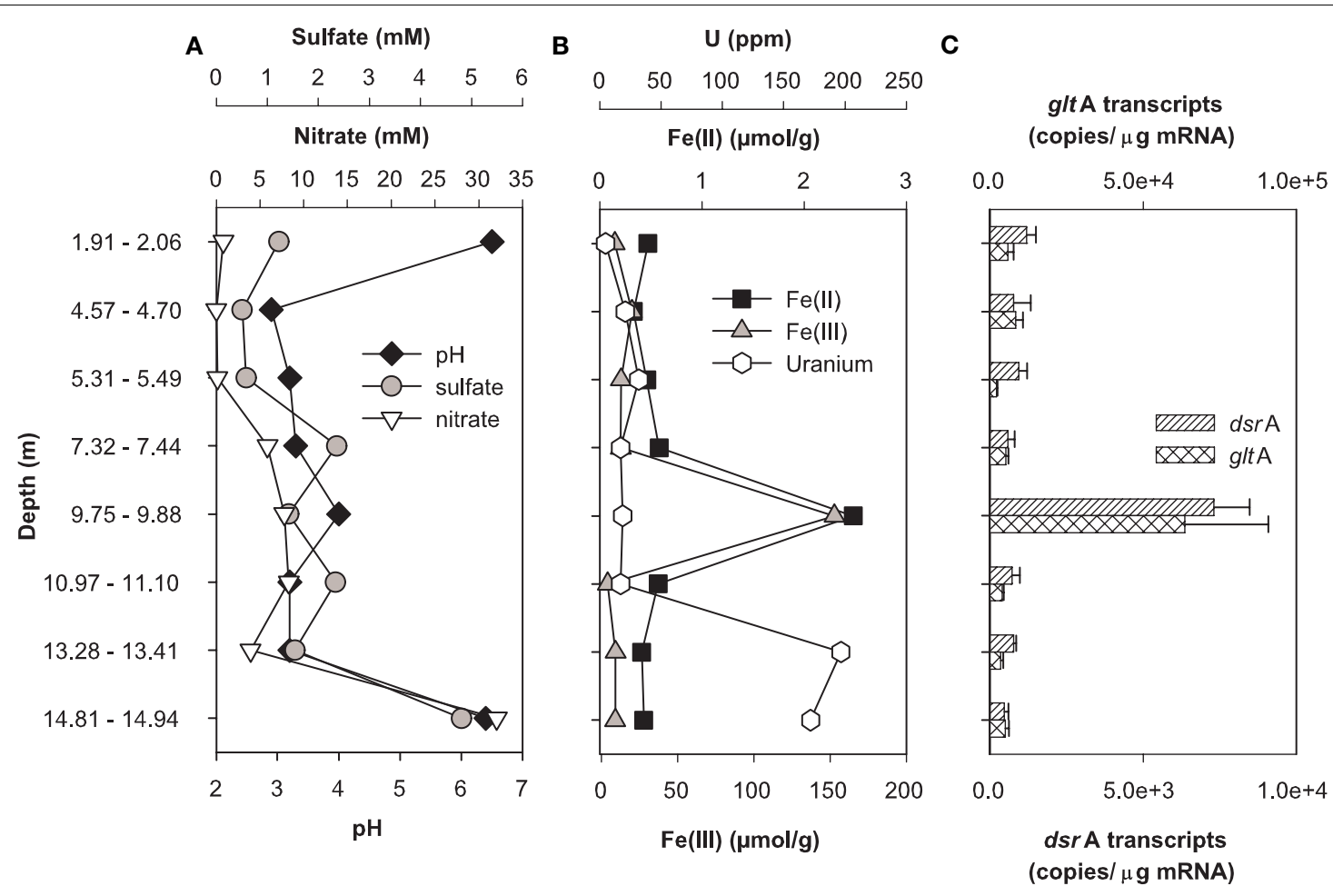

FIGURE 5 | Geochemistry $(\mathrm{A}, \mathrm{B})$ and levels of dsrA and gltA transcripts (C) in the depth interval from 5 to $7 \mathrm{~m}$ of Area 3 borehole FB124. Data for transcript levels are means \pm standard deviations of triplicate determinations on a pooled sample from triplicate borehole sediment samples. Nitrate, sulfate, $\mathrm{pH}$, iron, and uranium data were reported previously as supplemental material in Green et al. (2010). to the Geobacteraceae and encodes for an enzyme involved in the incorporation of acetate in to the TCA cycle (Bond et al., 2005; Holmes et al., 2005). To date, a total of 16 Geobacter species were isolated that are all capable of Fe(III) reduction (Lovley et al., 2004; Nevin et al., 2005, 2007; Sung et al., 2006; Shelobolina et al., 2007, 2008; Prakash et al., 2010). Eight of these isolates, Geobacter daltonii, G. uraniireducens, G. metallireducens, G. sulfurreducens, $G$. psychrophilus, G. bemidjiensis, G. lovleyii, and G. thiogenes, have citrate synthase genes available on the NCBI sequence database that are unique as they are eukaryote-like (Methe et al., 2003; Bond et al., 2005) distinguishing them from other prokaryotic FeRB and heterotrophs. The other isolates currently do not have genome sequences available so the genes have not been identified, but their similar metabolisms supports the inference that they may harbor the same, conserved citrate synthase gene. It is important to note that many organisms that are closely related to the Geobacteraceae do not possess a complete citric acid cycle or citrate synthase or have citrate synthase genes that are prokaryote-like instead of eukaryote-like. In addition, a closely related sulfate-reducer Desulfovibrio desulfuricans lacks citrate synthase in its genome, which was suggested by Bond et al. (2005) to indicate that citrate synthase was an important requirement in the evolution of Geobacteraceae to reduce $\mathrm{Fe}(\mathrm{III})$. We are aware that citrate synthase is not a molecular marker specifically for Fe(III) reduction, however it has been shown that its expression in pure cultures correlated directly with the central metabolism that was required for electron transfer to $\mathrm{Fe}$ (III) (Holmes et al., 2005).
Here we show for the first time that gene expression quantified as transcript levels of the Geobacteraceae clade of FeRB directly correlates with process rates and we identify specific microbial groups that are likely to catalyze metal reduction in situ. The competition between $\mathrm{Fe}$ (III) and sulfate reducers for carbon substrates could also be observed. In general, transcript levels of $d s r A$ and Geobacteraceae-specific gltA paralleled with the extent of sulfate and $\mathrm{Fe}$ (III) reduction, respectively, in all of our incubations. In the acetate-amended treatments, electron-accepting processes occurred according to thermodynamic predictions (Canfield et al., 2005). The bulk of the more energetically favorable process, $\mathrm{Fe}$ (III) reduction, occurred during the first 2 weeks of incubation, whereas most sulfate reduction occurred after 2 weeks. The rapid reduction of $\mathrm{Fe}$ (III) in acetate treatments was correlated with an increase in the expression of the Geobacteraceae-specific gltA gene, which indicates an increase in the growth and metabolism of members of the Geobacteraceae family. A recent study reported that Geobacter spp. grow rapidly after the addition of acetate to uraniumcontaminated sediments and that in conditions of excess electron donor their abundance is primarily controlled by the availability of microbially reducible Fe(III) (Barlett et al., 2012). In our microcosms amended with acetate and molybdate, we observed higher expression of gltA compared to the acetate treatment without molybdate. It is likely that this increase in gene expression in the presence of molybdate reflects the competition for electron donors between FeRB and SRB. With the addition of molybdate, the activity of SRB was depressed thereby removing competition 


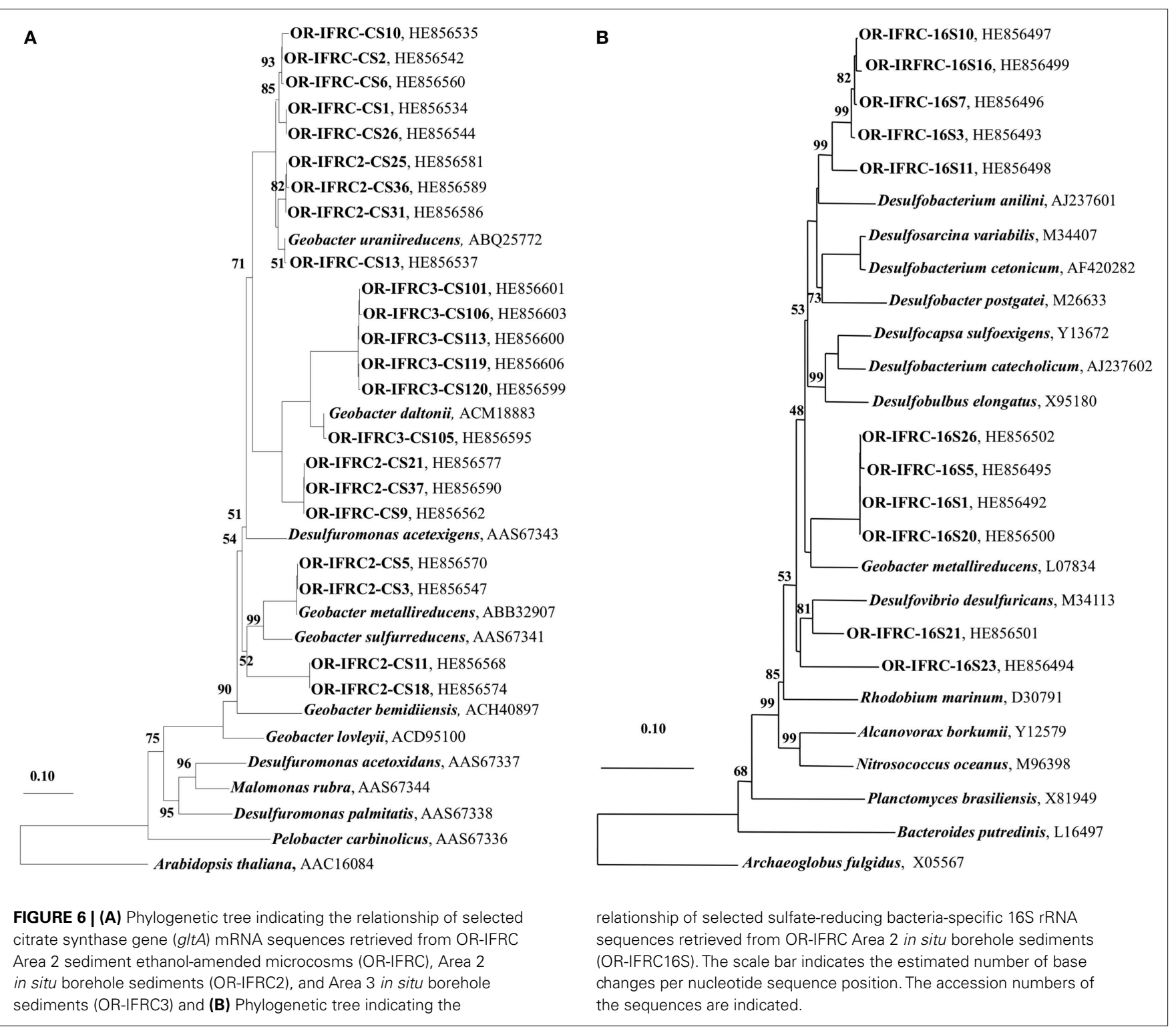

for added acetate. This conclusion is supported by our observation that acetate was consumed at a faster rate in the presence of molybdate. In contrast to Barlett et al. (2012), evidence from this study does not support the concurrent growth of FeRB and SRB in the presence of excess acetate. Rather, we conclude that in addition to Fe(III) availability, competition between FeRB and SRB is a key factor in limiting the activity of Geobacter during uranium bioremediation.

The choice of electron donor for bioremediation may directly impact $\mathrm{U}(\mathrm{VI})$ biotransformation by affecting the competition between FeRB and SRB. During OR-IFRC bioremediation experiments with ethanol, Fe(III) and sulfate reduction occurred simultaneously and SRB were more abundant than FeRB, suggesting that SRB play a more important role in $\mathrm{U}(\mathrm{VI})$ immobilization (Wu et al., 2007; Akob et al., 2008; Cardenas et al., 2008; Hwang et al., 2009). In corroboration of previous work, we observed concurrent $\mathrm{Fe}$ (III) and sulfate reduction in ethanol-amended

treatments, which goes against thermodynamic predictions (Canfield et al., 2005). The overlap in activity suggests that separate populations of $\mathrm{Fe}$ (III) and sulfate reducers were successfully competing for ethanol while reducing their preferred electron acceptor. It may be that SRB populations that couple reduction to ethanol oxidation are incapable of using Fe(III) thereby making sulfate the more energetic electron acceptor for their metabolism. Ethanol was first oxidized incompletely to acetate in the initial 6-8 days of incubation and then acetate was subsequently utilized by microbial consortia. Acetate was completely consumed in the ethanol only treatments, while $>1 \mathrm{mM}$ acetate remained in the treatments amended with ethanol + molybdate. This likely indicates that the microcosms were depleted in Fe(III) and sulfate was not utilized due to the fact that sulfate reducers were inhibited by molybdate. Ethanol addition resulted in the enhanced removal of soluble $\mathrm{U}(\mathrm{VI})$ relative to acetate amendment. 
Table 2 | Partial dsrA mRNA sequences retrieved from OR-IFRC ethanol-amended microcosms and in situ sediment.

\begin{tabular}{|c|c|c|c|}
\hline Source & Sequence designation & Closest relative (accession No.) & $\%$ Identity \\
\hline sediment microcosms & OR-IFRC-DSRsM2-12 & Desulfovibrio desulfuricans isolate SRDQC dsrAB genes (DO450464) & 96 \\
\hline & OR-IFRC-DSRsM1-4 & Uncultured prokaryote clone dsrSbl-66 dsrAB genes (AY167480) & 92 \\
\hline & OR-IFRC-DSRsM1-3 & $\begin{array}{l}\text { Uncultured sulfate-reducing bacterium dsrA gene clone LSsed06Jan-005 } \\
\text { (AB281007) }\end{array}$ & 86 \\
\hline & OR-IFRC-DSRsA2-4 & Desulfovibrio carbinolicus strain DSM 3852 dsrAB genes (AY626026) & 87 \\
\hline & OR-IFRC-DSRsA2-7 & Desulfovibrio desulfuricans subsp. desulfuricans dsrA gene (CAC09930) & 94 \\
\hline & OR-IFRC-DSRsA2-8 & Desulfovibrio desulfuricans subsp. desulfuricans dsrA gene (CAC09930) & 94 \\
\hline & OR-IFRC-DSRsA2-10 & Uncultured sulfate-reducing bacterium dsrA gene (BAF56324) & 97 \\
\hline Area 3 in situ sediments & OR-IFRC-DSRsA3-1 & Desulfotomaculum thermocisternum dsrA gene (AAC96107) & 84 \\
\hline
\end{tabular}

Sequence length is $116 \mathrm{bp}$ and all sequences were related to members of the Deltaproteobacteria.

Table 3 | Partial gltA mRNA sequences retrieved from OR-IFRC ethanol-amended microcosms and in situ sediment.

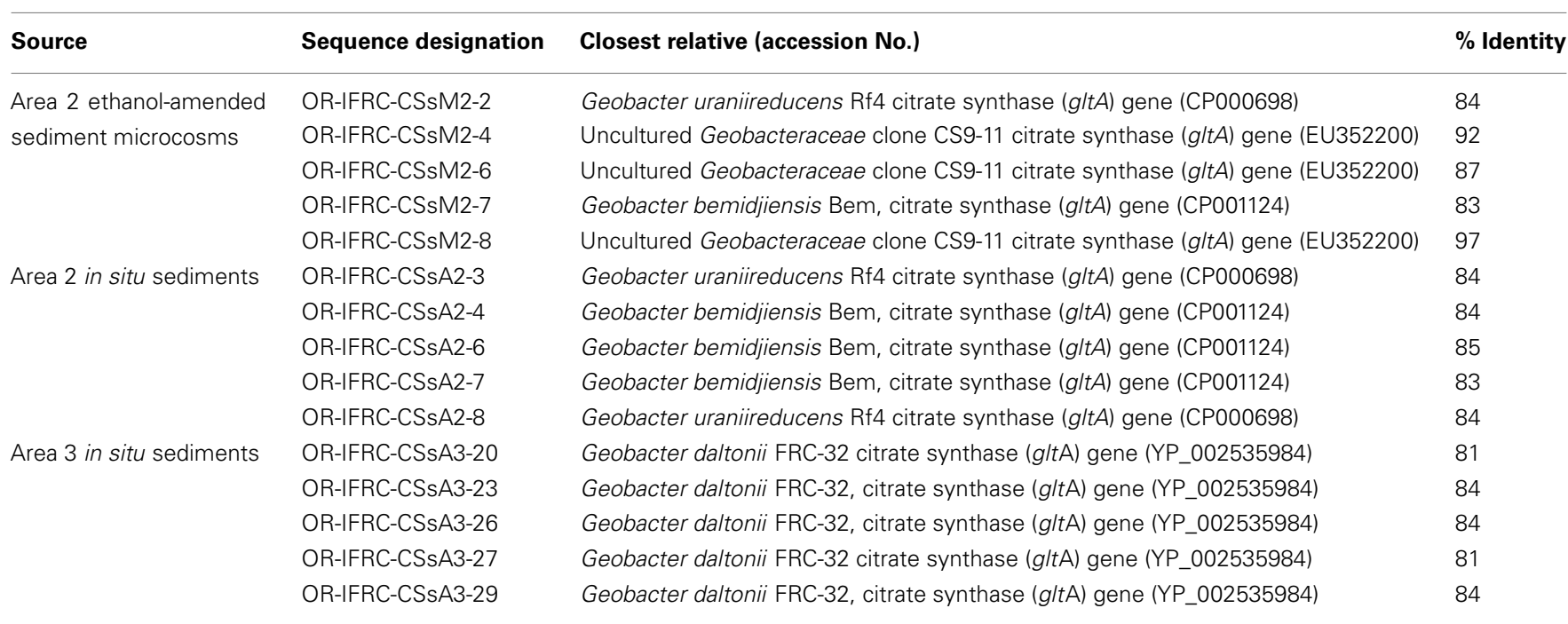

Sequence length is $224 \mathrm{bp}$ and all sequences were related to members of the Deltaproteobacteria.

Prior to the onset of active sulfate reduction, the levels of $d s r A$ transcripts increased in electron donor-amended microcosms and when sulfate concentrations were depleted, levels of $d s r \mathrm{~A}$ transcripts concurrently decreased. This is not surprising because $d s r A B$ codes for the dissimilatory (bi)sulfite reductase enzyme which is responsible for the rate-limiting step of sulfate reduction (Wagner et al., 1998). The increased $d s r A$ gene expression indicates the up regulation of the DSR operon, which is necessary for the cells to synthesize and to transport the enzymes needed to reduce the available sulfate. As expected in microcosms amended with molybdate to inhibit sulfate reduction the levels of $d s r A$ transcripts were at the lower limit of detection. Unlike the response of $d s r A$ transcripts, Geobacteraceae-specific gltA transcript levels did not increase prior to $\mathrm{Fe}(\mathrm{III})$ reduction but increased proportionally with $\mathrm{Fe}(\mathrm{III})$ reduction activity. This follows as gltA codes for an enzyme involved in the incorporation of acetate in to the TCA cycle (Bond et al., 2005; Holmes et al., 2005). Therefore, since gltA expression is not required for $\mathrm{Fe}$ (III) reduction but carbon metabolism, we would expect it to correlate more closely with acetate consumption. The increase in $g l t \mathrm{~A}$ expression indeed precedes consumption of acetate and indicates up regulation of the TCA cycle prior to acetate decrease. The quantification of Geobacteraceae-specific $g l t \mathrm{~A}$ transcripts verified a direct association between $\mathrm{Fe}(\mathrm{III})$ reduction and the oxidation of acetate. 


\section{PHYLOGENY OF ACTIVE METAL-REDUCING BACTERIA IN URANIUM-CONTAMINATED SEDIMENTS}

Quantification of gltA and $d s r A$ gene expression was successful in sediment samples from the moderately and highly contaminated OR-IFRC Areas 2 and 3, respectively. The observation that Geobacteraceae-related FeRB and SRB are metabolically active within borehole sediments without biostimulation provides evidence that these organisms are available to promote bioremediation and the long-term stability of reduced uranium in situ. The detection of transcripts in unamended subsurface sediments further demonstrates the sensitivity and specificity of the mRNAbased method. Previous studies found that Geobacteraceae-related FeRB and SRB were below detection in highly contaminated Area 3 of the OR-IFRC subsurface (Cardenas et al., 2008). We observed that transcript levels of $g l t A$ and $d s r A$ were low and only correlated with the abundance of electron acceptors in Area 3 sediments. Lower transcript levels in Area 2 sediments indicated that FeRB and SRB are active only at background levels, therefore their activity is not directly reflected in the prevailing biogeochemistry of the surrounding sediment. However, we cannot ignore the possibility that transport and sampling of sediments affected microbial activity and biased transcript analysis. For Area 3 sediments the highest levels of expression were associated with sediment zones with higher $\mathrm{Fe}$ (II) content and low sulfate concentrations. The low sulfate concentrations and high $d s r \mathrm{~A}$ transcript levels are indicative of on going sulfate reduction, whereas, gltA expression in regions with high $\mathrm{Fe}(\mathrm{II})$ concentrations indicated in situ activity of Geobacteraceae-related FeRB. The in situ activity of FeRB and SRB in Area 3 was surprising as this area is rich in nitrate, which serves as an alternative electron acceptor for FeRB and $\mathrm{SRB}$, due to close proximity to the source zone, and is limited in electron donors or carbon substrates. However, some species of Geobacter are known to reduce nitrate, such as G. humireducens (Coates et al., 1998) and G. metallireducens (Lovley et al., 1993b), and some species are known to oxidize aromatic hydrocarbons (Prakash et al., 2010) which are present in the contaminant plume of Area 3 (http://www.esd.ornl.gov/orifrc/). Although the conditions in Area 3 are more favorable for nitrate-reducing bacteria, which are adapted to the high nitrate, low $\mathrm{pH}$ in situ conditions (Green et al., 2012), active FeRB and SRB populations are present and active at low levels in situ. Such subsurface zones with high in situ activity of FeRB and SRB are likely the areas best suited for in situ bioremediation, as active microbial populations could quickly respond to the input of supplemental electron donor.

Members of the Geobacteraceae family are often detected in conjunction with metal reduction in the uranium-contaminated subsurface during biostimulation with the addition of electron donors, such as ethanol (North et al., 2004; Akob et al., 2008; Mohanty et al., 2008; Burkhardt et al., 2010; Sitte et al., 2010; Vishnivetskaya et al., 2010; Van Nostrand et al., 2011). The majority of cultivation-independent studies in subsurface sediments were conducted at the DNA level with SSU rRNA gene targets. In this study, the results of the phylogenetic analysis of gltA mRNA sequences demonstrated that members of the Geobacteraceae are abundant and metabolically active in biostimulated subsurface sediments. Further, our results suggest that members of the subsurface Geobacter clade, closely related to G. uraniireducens and $G$. daltonii, are metabolically active iron reducers that mediate metal reduction in OR-IFRC subsurface sediments. G. uraniireducens and $G$. daltonii were isolated from $\mathrm{U}(\mathrm{VI})$-contaminated subsurface environments at the Rifle and OR-IFRC sites, respectively (Shelobolina et al., 2008; Prakash et al., 2010), and these two species cluster with the phylogenetically coherent subsurface clade proposed by Holmes et al. (2007). Although these two Geobacter strains share $98.1 \%$ 16S rRNA gene sequence identity, their full genome sequences are highly divergent (Prakash et al., 2010). Limited physiological screening has begun to reveal substantial differences in electron acceptor and donor utilization within the subsurface clade of Geobacter. For example, G. daltonii and G. toluenxydans conserve energy for growth with aromatic contaminants as the electron donor, while G. uraniireducens does not (Kunapuli et al., 2010; Prakash et al., 2010). This may be explained by the fact that both G. daltonii and G. toluenoxydans were isolated from subsurface sediments contaminated with aromatic hydrocarbons, whereas G. uraniireducens was isolated from groundwater that was not substantially impacted by organic contaminants. A number of additional features may provide a competitive advantage to Geobacter in the subsurface including the ability to utilize acetate, chemotaxis, and nitrogen fixation (Childers et al., 2002; Holmes et al., 2004). Further quantitative analysis of gltA transcripts has the potential to aid in our understanding of the environmental controls of Geobacteraceae-mediated metal reduction. Primers designed for specific strains will likely reveal niche differentiation within the Geobacter family.

The active SRB observed during biostimulation and in intact core samples were related to members of the Desulfovibrionaceae and Desulfobacteraceae families within the Deltaproteobacteria and the Clostridia within the Firmicutes, and no sulfate-reducing Archaea were detected. This observation fits with previous studies at uranium-contaminated sites that correlated the activity of these organisms with the addition of carbon substrates (Chang et al., 2005; Akob et al., 2008; Burkhardt et al., 2010; Cardenas et al., 2010; Sitte et al., 2010; Vishnivetskaya et al., 2010; Miletto et al., 2011). The utilization of supplemental electron donors in our microcosms also fits with the known metabolism of the SRB detected, as ethanol is incompletely oxidized to acetate by Desulfovibrio and Desulfotomaculum species (Muyzer and Stams, 2008). In addition, both Desulfovibrio and Desulfotomaculum are known to enzymatically reduce U(VI) (Lovley and Phillips, 1992; Lovley et al., 1993a; Tebo and Obraztsova, 1998). This suggests that the activity of these organisms was directly related to the observed decrease in soluble uranium concentrations as was seen in earlier work (Akob et al., 2008; Cardenas et al., 2010; Vishnivetskaya et al., 2010; Van Nostrand et al., 2011). In environments co-contaminated with sulfate and nitrate such as the OR-IFRC, stimulation of Desulfovibrio may have a high bioremediation potential since the presence of sulfate represses nitrate reduction in this organism (Marietou et al., 2009). While members of the Desulfobacteraceae are known for acetate utilization and the complete oxidation of carbon substrates (Muyzer and Stams, 2008), these organisms have not been shown to reduce $\mathrm{U}(\mathrm{VI})$. Thus, it follows that we observed enhanced U(VI) immobilization under sulfate-reducing conditions when ethanol 
was used as the electron donor, whereas the linkage was not as strong when acetate was used.

\section{ACKNOWLEDGMENTS}

This research was supported by the Office of Science (BER), U.S. DOE grant no. DE-FG02-07ER64373, and by the Integrated FieldScale Subsurface Research Challenge at Oak Ridge, operated by

\section{REFERENCES}

Abdelouas, A., Lu, Y., Lutze, W., and Nuttall, H. (1998). Reduction of U(VI) to $\mathrm{U}(\mathrm{IV})$ by indigenous bacteria in contaminated ground water. J. Contam. Hydrol. 35, 217-233.

Akob, D. M., Mills, H. J., Gihring, T. M., Kerkhof, L., Stucki, J. W., Anastacio, A. S., Chin, K.-J., Küsel, K., Palumbo, A. V., Watson, D. B., and Kostka, J. E. (2008). Functional diversity and electron donor dependence of microbial populations capable of $\mathrm{U}(\mathrm{VI})$ reduction in radionuclide-contaminated subsurface sediments. Appl. Environ. Microbiol. 74, 3159-3170.

Altschul, S. F., Gish, W., Miller, W., Myers, E. W., and Lipman, D. J. (1990). Basic local alignment search tool. J. Mol. Biol. 215, 403-410.

Anderson, R. T., Vrionis, H. A., OrtizBernad, I., Resch, C. T., Long, P. E., Dayvault, R., Karp, K., Marutzky, S., Metzler, D. R., Peacock, A., White, D. C., Lowe, M., and Lovley, D. R. (2003). Stimulating the in situ activity of Geobacter species to remove uranium from the groundwater of a uranium-contaminated aquifer. Appl. Environ. Microbiol. 69, 5884-5891.

Barlett, M., Zhuang, K., Mahadevan, R., and Lovley, D. (2012). Integrative analysis of Geobacter spp. and sulfate-reducing bacteria during uranium bioremediation. Biogeosciences 9, 1033-1040.

Bond, D. R., Mester, T., Nesbo, C. L., Izquierdo-Lopez, A. V., Collart, F. L., and Lovley, D. R. (2005). Characterization of citrate synthase from Geobacter sulfurreducens and evidence for a family of citrate synthases similar to those of eukaryotes throughout the Geobacteraceae. Appl. Environ. Microbiol. 71, 3858-3865.

Brina, R., and Miller, A. G. (1992). Direct detection of trace levels of uranium by laser-induced kinetic phosphorimetry. Anal. Chem. 64, 1413-1418.

Burkhardt, E.-M., Akob, D. M., Bischoff, S., Sitte, J., Kostka, J. E., Banerjee, D., Scheinost, A. C., and Küsel, K. (2010). Impact of biostimulated redox processes on metal dynamics in an iron-rich creek soil of a former uranium mining area. Environ. Sci. Technol. 44, 177-183.

Butler, J. E., Young, N. D., and Lovley, D. R. (2010). Evolution of electron transfer out of the cell: comparative genomics of six Geobacter genomes. BMC Genomics 11, 40. doi:10.1186/1471-2164-11-40

Canfield, D. E., Kristensen, E., and Thamdrup, B. (2005). Chapter 6: the iron and manganese cycles. Aquat. Geomicrobiol. 48, 1-65.

Cardenas, E., Wu, W.-M., Leigh, M. B., Carley, J., Carroll, S., Gentry, T., Luo, J., Watson, D., Gu, B., Ginder-Vogel, M., Kitanidis, P. K., Jardine, P. M., Zhou, J., Criddle, C. S., Marsh, T. L., and Tiedje, J. M. (2008). Microbial communities in contaminated sediments, associated with bioremediation of uranium to submicromolar levels. Appl. Environ. Microbiol. 74, 3718-3729. Carley, J., Carroll, S., Gentry, T., Luo, J., Watson, D., Gu, B., Ginder-Vogel, M., Kitanidis, P. K., Jardine, P. M., Zhou, J., Criddle, C. S., Marsh, T. L., and Tiedje, J. M. (2010). Significant association between sulfate-reducing bacteria and uranium-reducing microbial communities as revealed by a combined massively parallel sequencingindicator species approach. Appl. Environ. Microbiol. 76, 6778-6786.

Cataldo, D. A., Haroon, M., Schrader, L. E., and Youngs, V. L. (1975). Rapid colorimetric determination of nitrate in plant tissue by nitration of salicylic acid. Commun. Soil Sci. Plant Anal. 6, 71-80.

Chang, Y. J., Long, P. E., Geyer, R., Peacock, A. D., Resch, C. T., Sublette, K., Pfiffner, S., Smithgall, A., Anderson, R. T., Vrionis, H. A., Stephen, J. R., Dayvault, R., Ortiz-Bernad, I., Lovley, D. R., and White, D. C. (2005). Microbial incorporation of C-13-labeled acetate at the field scale: detection of microbes responsible for reduction of U(VI). Environ. Sci. Technol. 39, 9039-9048.

Childers, S. E., Ciufo, S., and Lovley, D. R. (2002). Geobacter metallireducens
Cardenas, E., Wu, W.-M., Leigh, M. B.

the Environmental Sciences Division, ORNL, under U.S. DOE contract no. DE-AC05-00OR22725. Denise M. Akob was supported by a Marie-Curie Postdoctoral Research Fellowship during preparation of the manuscript. We thank Lisa Fagan for sediment sampling and collaboration and Andrew Madden for providing the U(VI) analyses. We also thank Mike Humphrys for helpful discussions.

accesses insoluble $\mathrm{Fe}(\mathrm{III})$ oxide by chemotaxis. Nature 416, 767-769.

Chin, K.-J., Sharma, M., Russell, L. O'Neill, K., and Lovley, D. (2008). Quantifying expression of a dissimilatory (bi)sulfite reductase gene in petroleum-contaminated marine harbor sediments. Microb. Ecol. 55, 489-499.

Chin, K.-J., Esteve-Nunez, A., Leang, C., and Lovley, D. R. (2004). Direct correlation between rates of anaerobic respiration and levels of mRNA for key respiratory genes in Geobacter sulfurreducens. Appl. Environ. Microbiol. 70, 5183-5189.

Coates, J. D., Ellis, D. J., Blunt-Harris, E. L., Gaw, C. V., Roden, E. E., and Lovley, D. R. (1998). Recovery of humic-reducing bacteria from a diversity of environments. Appl. Environ. Microbiol. 64, 1504-1509.

Daly, K., Sharp, R. J., and McCarthy, A. J. (2000). Development of oligonucleotide probes and PCR primers for detecting phylogenetic subgroups of sulfate-reducing bacteria. Microbiology 146, 1693-1705.

DiChristina, T. J. (2005a). Enzymology of electron transport: energy generation with geochemical consequences. Rev. Mineral. Geochem. 59, 27-52.

DiChristina, T. J. (2005b). New insights into the molecular mechanism of microbial metal respiration. Geochim. Cosmochim. Acta 69, A670.

Finneran, K. T., Anderson, R. T., Nevin, K. P., and Lovley, D. R. (2002). Potential for bioremediation of uranium-contaminated aquifers with microbial U(VI) reduction. Soil Sediment Contam. 11, 339-357.

Green, S. J., Prakash, O., Gihring, T. M., Akob, D. M., Jasrotia, P., Jardine, P. M., Watson, D. B., Brown, S. D., Palumbo, A. V., and Kostka, J. E. (2010). Denitrifying bacteria isolated from terrestrial subsurface sediments exposed to mixed-waste contamination. Appl. Environ. Microbiol. 76, 3244-3254.

Green, S. J., Prakash, O., Jasrotia, P., Overholt, W. A., Cardenas, E., Hubbard, D., Tiedje, J. M., Watson, D. B., Schadt, C. W., Brooks, S. C., and Kostka, J. E. (2012). Denitrifying bacteria from the genus
Rhodanobacter dominate bacterial communities in the highly contaminated subsurface of a nuclear legacy waste site. Appl. Environ. Microbiol. 78, 1039-1047.

Groudev, S., Spasova, I., Nicolova, M., and Georgiev, P. (2010). In situ bioremediation of contaminated soils in uranium deposits. Hydrometallurgy 104, 518-523.

Holmes, D., Nevin, K., and Lovley, D. (2004). In situ expression of nifD in Geobacteraceae in subsurface sediments. Appl. Environ. Microbiol. 70, 7251-7259.

Holmes, D. E., Finneran, K. T., O’Neil, R. A., and Lovley, D. R. (2002). Enrichment of members of the family Geobacteraceae associated with stimulation of dissimilatory metal reduction in uraniumcontaminated aquifer sediments. Appl. Environ. Microbiol. 68 , 2300-2306.

Holmes, D. E., Nevin, K. P., O’Neil, R. A., Ward, J. E., Adams, L. A., Woodard, T. L., Vrionis, H. A., and Lovley, D. R. (2005). Potential for quantifying expression of the Geobacteraceae citrate synthase gene to assess the activity of Geobacteraceae in the subsurface and on currentharvesting electrodes. Appl. Environ. Microbiol. 71, 6870-6877.

Holmes, D. E., O’Neil, R. A., Vrionis, H. A., N'Guessan, L. A., Ortiz-Bernad, I., Larrahondo, M. J., Adams, L. A., Ward, J. A., Nicoll, J. S., Nevin, K. P., Chavan, M. A., Johnson, J. P., Long, P. E., and Lovley, D. R. (2007). Subsurface clade of Geobacteraceae that predominates in a diversity of $\mathrm{Fe}$ (III)-reducing subsurface environments. ISME J. 1, 663-677.

Hua, B., Xu, H., Terry, J., and Deng, B. (2006). Kinetics of uranium(VI) reduction by hydrogen sulfide in anoxic aqueous systems. Environ. Sci. Technol. 40, 4666-4671.

Hwang, C., Wu, W., Gentry, T. J., Carley, J., Corbin, G. A., Carroll, S. L., Watson, D. B., Jardine, P. M., Zhou, J., Criddle, C. S., and Fields, M. W. (2009). Bacterial community succession during in situ uranium bioremediation: spatial similarities along controlled flow paths. ISME J. 3, 47-64. 
Kostka, J. E., and Green, S. J. (2011). "Microorganisms and processes linked to uranium reduction and immobilization," in Microbial Metal and Metalloid Metabolism: Advances and Applications, eds J. F. Stolz and R. S. Oremland (Washington, DC: ASM Press), 117-138.

Kostka, J. E., and Luther, G. W. (1994). Partitioning and speciation of solidphase iron in salt-marsh sediments. Geochim. Cosmochim. Acta 58, 1701-1710.

Kunapuli, U., Jahn, M. K., Lueders, T., Geyer, R., Heipieper, H. J., and Meckenstock, R. U. (2010). Desulfitobacterium aromaticivorans sp. nov. and Geobacter toluenoxydans sp. nov., iron-reducing bacteria capable of anaerobic degradation of monoaromatic hydrocarbons. Int. J. Syst. Evol. Microbiol. 60, 686-695.

Liger, E., Charlet, L., and Van Cappellen, P. (1999). Surface catalysis of uranium(VI) reduction by iron(II). Geochim. Cosmochim. Acta 63, 2939-2955.

Lovley, D., Holmes, D., and Nevin, K. (2004). Dissimilatory Fe(III)and $\mathrm{Mn}(\mathrm{IV})$ reduction. Adv. Microb. Physiol. 49, 68.

Lovley, D., Widman, P., Woodward, J., and Phillips, E. (1993a). Reduction of uranium by cytochrome c3 of Desulfovibrio vulgaris. Appl. Environ. Microbiol. 59, 3572-3576.

Lovley, D. R., Giovannoni, S. J., White, D. C., Champine, J. E., Phillips, E. J. P., Gorby, Y. A., and Goodwin, S. (1993b). Geobacter metallireducens gen. nov. sp. nov., a microorganism capable of coupling the complete oxidation of organic compounds to the reduction of iron and other metals. Arch. Microbiol. 159, 336-344.

Lovley, D. R., and Phillips, E. J. (1992). Reduction of uranium by Desulfovibrio desulfuricans. Appl. Environ. Microbiol. 58, 850-856.

Ludwig, W., Strunk, O., Westram, R., Richter, L., Meier, H., Yadhukumar, Buchner, A., Lai, T., Steppi, S., Jobb, G., Forster, W., Brettske, I., Gerber, S., Ginhart, A. W., Gross, O., Grumann, S., Hermann, S., Jost, R., Konig, A., Liss, T., Lussmann, R., May, M., Nonhoff, B., Reichel, B., Strehlow, R., Stamatakis, A., Stuckmann, N., Vilbig, A., Lenke, M., Ludwig, T., Bode, A., and Schleifer, K.-H. (2004). ARB: a software environment for sequence data. Nucleic Acids Res. 32, 1363-1371.

Marietou, A., Griffiths, L., and Cole, J. (2009). Preferential reduction of the thermodynamically less favorable electron acceptor, sulfate, by a nitrate-reducing strain of the sulfate-reducing bacterium Desulfovibrio desulfuricans 27774. J. Bacteriol. 191, 882-889.

McLean, E. O. (1982). "Soil pH and lime requirement," in Methods of Soil Analysis: Part 2, Chemical and Microbiological Properties, 2nd Edn, eds A. L. Page, R. H. Miller, and D. R. Keeney (Madison, WI: American Society of Agronomy), 199-209.

Methe, B. A., Nelson, K. E., Eisen, J. A., Paulsen, I. T., Nelson, W., Heidelberg, J. F., Wu, D., Wu, M., Ward, N., Beanan, M. J., Dodson, R. J., Madupu, R., Brinkac, L. M., Daugherty, S. C., DeBoy, R. T., Durkin, A. S., Gwinn, M., Kolonay, J. F., Sullivan, S. A., Haft, D. H., Selengut, J., Davidsen, T. M., Zafar, N., White, O., Tran, B., Romero, C., Forberger, H. A., Weidman, J., Khouri, H., Feldblyum, T. V., Utterback, T. R., Van Aken, S. E., Lovley, D. R., and Fraser, C. M. (2003). Genome of Geobacter sulfurreducens: metal reduction in subsurface environments. Science 302, 1967-1969.

Michalsen, M. M., Peacock, A. D., Smithgal, A. N., White, D. C., Spain, A. M., Sanchez-Rosario, Y., Krumholz, L. R., Kelly, S. D., Kemner, K. M., McKinley, J., Heald, S. M., Bogle, M. A., Watson, D. B., and Istok, J. D. (2009). Treatment of nitric acid-, U(VI)-, and $\mathrm{Tc}(\mathrm{VII})$-contaminated groundwater in intermediate-scale physical models of an in situ biobarrier. Environ. Sci. Technol. 43, 1952-1961.

Miletto, M., Williams, K. H., N'Guessan, A. L., and Lovley, D. R. (2011). Molecular analysis of the metabolic rates of discrete subsurface populations of sulfate reducers. Appl. Environ. Microbiol. 77, 6502-6509.

Mohanty, S. R., Kollah, B., Hedrick, D., Peacock, A. D., Kukkadapu, R. K., and Roden, E. E. (2008). Biogeochemical processes in ethanol stimulated uranium-contaminated subsurface sediments. Environ. Sci. Technol. 42, 4384-4390.

Muyzer, G., and Stams, A. J. M. (2008). The ecology and biotechnology of sulphate-reducing bacteria. Nat. Rev. Microbiol. 6, 441-454.

Neretin, L. N., Schippers, A., Pernthaler, A., Hamann, K., Amann, R., and Jørgensen, B. B. (2003). Quantification of dissimilatory (bi)sulphite reductase gene expression in Desulfobacterium autotrophicum using realtime RT-PCR. Environ. Microbiol. 5, 660-671.

Nevin, K. P., Holmes, D. E., Woodard, T. L., Covalla, S. F., and Lovley,
D. R. (2007). Reclassification of Trichlorobacter thiogenes as Geobacter thiogenes comb. nov. Int. J. Syst. Evol. Microbiol. 57, 463-466.

Nevin, K. P., Holmes, D. E., Woodard, T. L., Hinlein, E. S., Ostendorf, D.W., and Lovley, D. R. (2005). Geobacter bemidjiensis sp. nov. and Geobacter psychrophilus sp. nov., two novel $\mathrm{Fe}(\mathrm{III})$-reducing subsurface isolates. Int. J. Syst. Evol. Microbiol. 55, 1667-1674.

North, N., Dollhopf, S., Petrie, L., Istok, J., Balkwill, D., and Kostka, J. (2004). Change in bacterial community structure during in situ biostimulation of subsurface sediment cocontaminated with uranium and nitrate. Appl. Environ. Microbiol. 70, 4911-4920.

Palmisano, A., and Hazen, T. (2003). Bioremediation of Metals and Radionuclides: What It Is and How It Works, 2nd Edn. Berkeley: Lawrence Berkeley National Laboratory. Available at: http:// escholarship.org/uc/item/7md2589q

Payne, A. N., and DiChristina, T. J. (2006). A rapid mutant screening technique for detection of technetium $[\mathrm{Tc}(\mathrm{VII})]$ reductiondeficient mutants of Shewanella oneidensis MR-1. FEMS Microbiol. Lett. 259, 282-287.

Prakash, O., Gihring, T. M., Dalton, D. D., Chin, K.-J., Green, S. J., Akob, D. M., Wanger, G., and Kostka, J. E. (2010). Geobacter daltonii sp. nov., an $\mathrm{Fe}(\mathrm{III})-$ and uranium(VI)reducing bacterium isolated from a shallow subsurface exposed to mixed heavy metal and hydrocarbon contamination. Int. J. Syst. Evol. Microbiol. 60, 546-553.

Rodier, J. (1975). L'analyse de l'eau, 5th Edn. Paris: Dunod.

Röling, W. F. M., van Breukelen, B. M., Braster, M., Lin, B., and van Verseveld, H. W. (2001). Relationships between microbial community structure and hydrochemistry in a landfill leachate-polluted aquifer. Appl. Environ. Microbiol. 67, 4619-4629.

Rooney-Varga, J. N., Anderson, R. T., Fraga, J. L., Ringelberg, D., and Lovley, D. R. (1999). Microbial communities associated with anaerobic benzene degradation in a petroleumcontaminated aquifer. Appl. Environ. Microbiol. 65, 3056-3063.

Sani, R. (2004). Reduction of uranium(VI) under sulfate-reducing conditions in the presence of $\mathrm{Fe}$ (III)(hydr)oxides. Geochim. Cosmochim. Acta 68, 2639-2648.

Shelobolina, E., Nevin, K., BlakeneyHayward, J., Johnsen, C., Plaia, T.,
Krader, P., Woodard, T., Holmes, D., Vanpraagh, C., and Lovley, D. (2007). Geobacter pickeringii sp. nov., Geobacter argillaceus sp. nov. and Pelosinus fermentans gen. nov., sp. nov., isolated from subsurface kaolin lenses. Int. J. Syst. Evol. Microbiol. 57, 126-135.

Shelobolina, E., Vrionis, H., Findlay, R., and Lovley, D. (2008). Geobacter uraniireducens sp. nov., isolated from subsurface sediment undergoing uranium bioremediation. Int. J. Syst. Evol. Microbiol. 58, 1075-1078.

Sitte, J., Akob, D. M., Kaufmann, C., Finster, K., Banerjee, D., Burkhardt, E.-M., Kostka, J. E., Scheinost, A. C., Büchel, G., and Küsel, K. (2010). Microbial links between sulfate reduction and metal retention in uranium- and heavy metalcontaminated soil. Appl. Environ. Microbiol. 76, 3143-3152.

Snoeyenbos-West, O. L., Nevin, K. P., Anderson, R.T., and Lovley, D. R. (2000). Enrichment of Geobacter species in response to stimulation of $\mathrm{Fe}(\mathrm{III})$ reduction in sandy aquifer sediments. Microb. Ecol. 39, 153167.

Sung, Y., Fletcher, K. E., Ritalahti, K. M., Apkarian, R. P., Ramos-Hernández, N., Sanford, R. A., Mesbah, N. M. and Löffler, F. E. (2006). Geobacter lovleyi sp. nov. strain SZ, a novel metal-reducing and tetra chloroethene-dechlorinating bacterium. Appl. Environ. Microbiol. 72, 2775-2782.

Tebo, B. M., and Obraztsova, A. Y. (1998). Sulfate-reducing bacterium grows with $\mathrm{Cr}(\mathrm{VI}), \mathrm{U}(\mathrm{VI}), \mathrm{Mn}(\mathrm{IV})$, and $\mathrm{Fe}(\mathrm{III})$ as electron acceptors. FEMS Microbiol. Lett. 162, 193-198.

Van Nostrand, J. D., Wu, L., Wu, W.M., Huang, Z., Gentry, T. J., Deng, Y., Carley, J., Carroll, S., He, Z., Gu, B., Luo, J., Criddle, C. S., Watson, D. B., Jardine, P. M., Marsh, T. L., Tiedje, J. M., Hazen, T. C., and Zhou, J. (2011). Dynamics of microbial community composition and function during in situ bioremediation of a uranium-contaminated aquifer. Appl. Environ. Microbiol. 77, 3860-3869.

Villanueva, L., Haveman, S. A., Summers, Z. M., and Lovley, D. R. (2008). Quantification of Desulfovibrio vulgaris dissimilatory sulfite reductase gene expression during electron donor- and electron acceptor-limited growth. Appl. Environ. Microbiol. 74, 5850-5853.

Vishnivetskaya, T. A., Brandt, C. C., Madden, A. S., Drake, M. M., Kostka, 
J. E., Akob, D. M., Küsel, K., and Palumbo, A. V. (2010). Microbial community changes in response to ethanol or methanol amendments for U(VI) reduction. Appl. Environ. Microbiol. 76, 5728-5735.

Wagner, M., Roger, A. J., Flax, J. L., Brusseau, G. A., and Stahl, D. A. (1998). Phylogeny of dissimilatory sulfite reductases supports an early origin of sulfate respiration. J. Bacteriol. 180, 2975-2982.

Wall, J. D., and Krumholz, L. (2006). Uranium reduction. Annu. Rev. Microbiol. 60, 149-166.

Widdel, F., and Bak, F. (1992). "Gram-negative mesophilic sulfatereducing bacteria," in The Prokaryotes, eds A. Balows, H. G. Trüper, M. Dworkin, W. Harder, and K.-H. Schleifer (New York, NY: Springer), 3352-3378.
Wilkins, M., Livens, F., Vaughan, D., and Lloyd, J. (2006). The impact of $\mathrm{Fe}$ (III)-reducing bacteria on uranium mobility. Biogeochemistry 78, 125-150.

Wu, W., Carley, J., Gentry, T., GinderVogel, M., Fienen, M., Mehlhorn, T., Yan, H., Caroll, S., Pace, M., Nyman, J., Luo, J., Gentile, M., Fields, M., Hickey, R., Gu, B., Watson, D., Cirpka, O., Zhou, J., Fendorf, S., Kitanidis, P., Jardine, P., and Criddle, C. (2006). Pilot-scale in situ bioremedation of uranium in a highly contaminated aquifer. 2. reduction of $\mathrm{U}(\mathrm{VI})$ and geochemical control of U(VI) bioavailability. Environ. Sci. Technol. 40, 3986-3995.

Wu, W. M., Carley, J., Luo, J., GinderVogel, M. A., Cardenas, E., Leigh, M. B., Hwang, C., Kelly, S. D., Ruan,
C., Wu, L., Van Nostrand, J., Gentry, T., Lowe, K., Mehlhorn, T., Carroll, S., Luo, W., Fields, M. W., Gu, B. Watson, D., Kemner, K. M., Marsh, T., Tiedje, J., Zhou, J., Fendorf, S. Kitanidis, P. K., Jardine, P. M., and Criddle, C. S. (2007). In situ bioreduction of uranium(VI) to submicromolar levels and reoxidation by dissolved oxygen. Environ. Sci. Technol. 41, 5716-5723.

Conflict of Interest Statement: The authors declare that the research was conducted in the absence of any commercial or financial relationships that could be construed as a potential conflict of interest.

Received: 18 May 2012; accepted: 18 July 2012; published online: 09 August 2012.
Citation: Akob DM, Lee SH, Sheth $M$, Küsel $K$, Watson DB, Palumbo AV, Kostka JE and Chin K-J (2012) Gene expression correlates with process rates quantified for sulfate- and $\mathrm{Fe}(\mathrm{III})$-reducing bacteria in U(VI)-contaminated sediments. Front. Microbio. 3:280. doi: 10.3389/fmicb.2012.00280

This article was submitted to Frontiers in Terrestrial Microbiology, a specialty of Frontiers in Microbiology.

Copyright (C) 2012 Akob, Lee, Sheth, Küsel, Watson, Palumbo, Kostka and Chin. This is an open-access article distributed under the terms of the Creative Commons Attribution License, which permits use, distribution and reproduction in other forums, provided the original authors and source are credited and subject to any copyright notices concerning any third-party graphics etc. 